This PDF is a selection from an out-of-print volume from the National Bureau of Economic Research

Volume Title: Tax Policy and the Economy, Volume 8

Volume Author/Editor: James M. Poterba

Volume Publisher: MIT Press

Volume ISBN: 0-262-66091-1

Volume URL: http://www.nber.org/books/pote94-3

Conference Date: November 16, 1993

Publication Date: January 1994

Chapter Title: Welfare and the Well-Being of Children: The Relative Effectiveness of Cash and In-Kind Transfers

Chapter Author: Janet Currie

Chapter URL: http://www.nber.org/chapters/c10883

Chapter pages in book: (p. 1 - 44) 


\section{WELFARE AND THE}

WELL-BEING OF CHILDREN: THE RELATIVE EFFECTIVENESS OF CASH AND IN-KIND TRANSFERS

\section{Janet Currie}

University of California, Los Angeles and NBER

\section{EXECUTIVE SUMMARY}

Cash transfers to families with children are being restricted increasingly to parents who work, while families of nonworking parents are receiving a progressively larger share of their benefits in kind. This paper provides an evaluation of the empirical evidence regarding the effects of in-kind and cash-transfer programs on the children who are their intended beneficiaries. A distinction is made between in-kind transfer programs, such as the Food Stamp Program, which provide transfers to families that are earmarked for certain purposes, and programs such as Medicaid that provide specific services directly to children. Although the evidence is incomplete, it suggests that in-kind programs have stronger effects on children than cash transfers, and that programs that target specific benefits directly to children have the largest positive effects.

I would like to thank Anne Pebley, James Poterba, and Duncan Thomas for useful comments and discussions. Vandy Howell and Jodi Fingerman provided excellent research assistance. Financial support from the National Science Foundation under grant number SES-9122640, and from the National Bureau of Economic Research's Olin Fellows Program is gratefully acknowledged. 


\section{INTRODUCTION}

Although the public identifies the term welfare with cash transfers to single mothers under the Aid to Families with Dependent Children program (AFDC), cash transfers are being restricted increasingly to parents who work. The nonworking poor are receiving a progressively larger share of their benefits in kind (Moffitt, 1992). In a world in which governments could always identify the intended beneficiaries, and issues of intra-household resource allocation did not arise, in-kind transfers to poor families would be an inefficient way to increase the well-being of poor children. The "first-best" solution would be to allow families on welfare to choose the basket of goods that best suited their needs.

In reality, it is necessary to design welfare programs that discourage those outside the targeted population from applying. Nichols and Zeckhauser (1982) show that if governments can identify goods that are valued more highly by the deserving poor than by potential "imposters," then providing these benefits in kind is a more efficient way to transfer resources than providing cash, because fewer resources will be directed to imposters. Besley and Coate (1992) provide a similar analysis of requirements that welfare participants work. These papers provide a theoretical justification for restrictions on cash welfare and for the growing emphasis on in-kind transfers. The literature on intra-household resource allocation further suggests that policy makers should be concerned with how resources are utilized within the family. ${ }^{1}$

This paper provides an evaluation of the empirical evidence regarding the effects of eight large federal cash and in-kind transfer programs on the children who are their intended beneficiaries. It is convenient to divide in-kind transfers into two groups: those that provide transfers to the families of poor children that are earmarked for certain purposes (e.g., food stamps), and those that provide specific services directly to children (e.g., Medicaid). The evidence reviewed here suggests that inkind programs have stronger effects on children than cash transfers, and that the more narrowly targeted the program, the larger the effects.

The second section of the paper provides an overview of the major federal welfare programs that benefit children and documents the trends toward in-kind benefits and toward restrictions on cash transfers. Measures of child well-being are also discussed. The third section discusses the evidence regarding the effects of cash transfers on children. Section 4 analyzes in-kind transfers and discusses the relative efficacy of ear-

1 For example, Thomas (1993) discusses the effects of allocating resources to mothers rather than to fathers. 


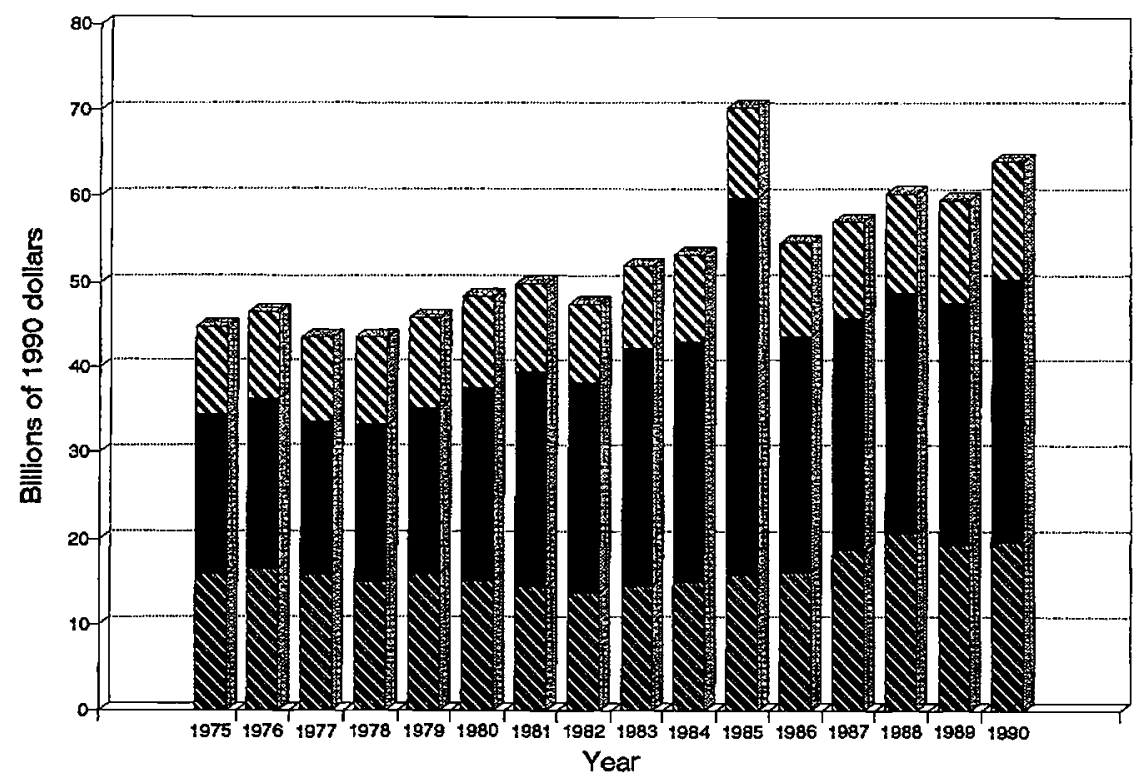

DI CASH DAPMAGKED DO INKWND

\section{FIGURE 1. Federal Welfare Expenditures.}

Note: The bulge in outlays in 1985 is caused by a change in the method of financing public housing, which generated close to $\$ 14$ billion in one-time expenditures. The costs of capital expenditures and modernization activities undertaken between 1974 and 1985 were paid off in one lump sum rather than having payments spread over periods up to forty years. Because of this one-time expenditure, future outlays for public housing will be lower than they otherwise would have been.

marked versus more narrowly targeted programs. Conclusions appear in Section 5.

\section{BACKGROUND}

\subsection{An Overview of the Federal Welfare System ${ }^{2}$}

Figure 1 shows the evolution of federal expenditures on the eight largest welfare programs benefiting children. Administrative costs are excluded whenever possible, as are state matching contributions for AFDC and Medicaid. Expenditures (in real 1990 dollars) have been divided into cash transfers and two types of in-kind transfers: "earmarked" programs in-

2 Unless otherwise noted, the information in this section comes from the U.S. House of Representatives $(1991,1992)$. 


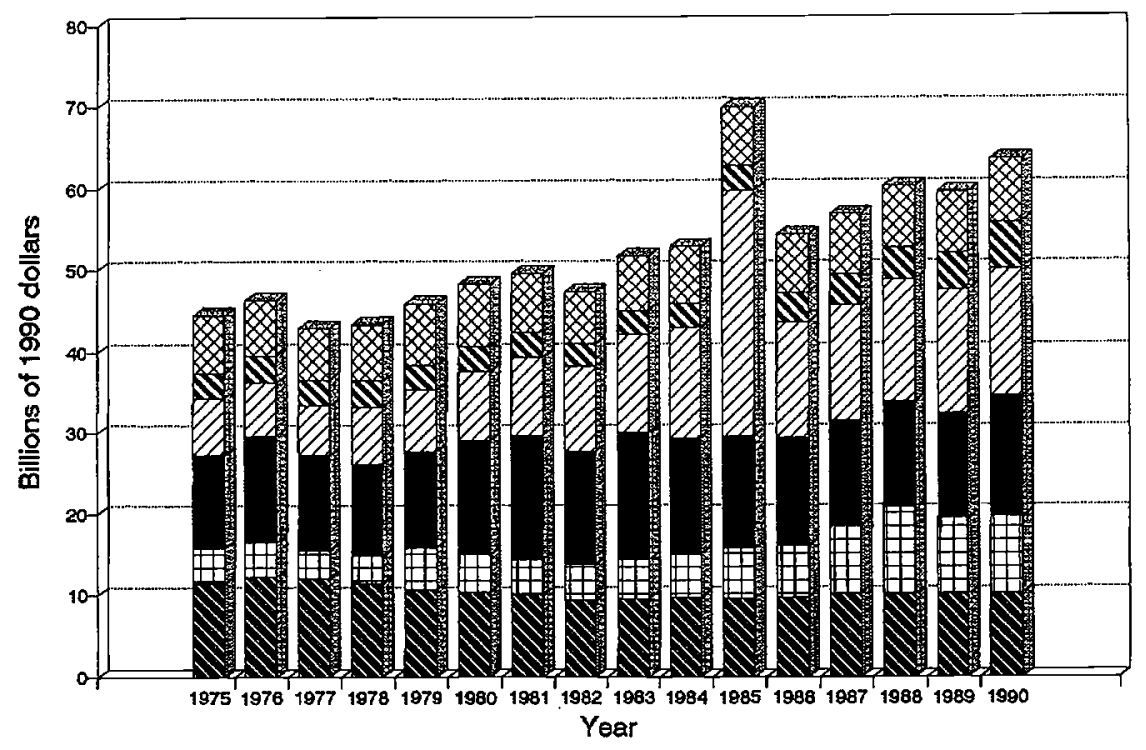

\begin{tabular}{|c|c|c|}
\hline NA AFDC & \# & $\begin{array}{l}\text { FOODSTAMP } \\
\text { OTHER INKND }\end{array}$ \\
\hline
\end{tabular}

\section{FIGURE 2. Federal Welfare Expenditures.}

Note: The bulge in outlays in 1985 is caused by a change in the method of financing public housing, which generated close to $\$ 14$ billion in one-time expenditures. The costs of capital expenditures and modernization activities undertaken between 1974 and 1985 were paid off in one lump sum rather than having payments spread over periods up to forty years. Because of this one-time expenditure, future outlays for public housing will be lower than they otherwise would have been.

clude food stamps and housing assistance; "targeted" programs include Medicaid, Head Start, the National School Lunch Program (NSLP), and the Special Supplemental Feeding Program for Women, Infants, and Children (WIC). The figure shows the remarkable increase in in-kind benefits relative to cash benefits: though cash transfers grew only 18 percent between 1975 and 1990, in-kind transfers shot up 51 percent. Earmarked programs make up the bulk of expenditures on in-kind programs, but the two types of in-kind programs have shown roughly equal growth over time. ${ }^{3}$

Figure 2 provides a more detailed breakdown of the evolution of ex-

${ }^{3}$ It is interesting to compare these outlays on children to federal expenditures on the elderly. In 1990, the federal government spent $\$ 1,020$ per child under eighteen compared to $\$ 11,350$ per elderly person (U.S. House of Representatives, 1992). The largest component of spending on the elderly was Social Security, which came to $\$ 193$ billion. 
TABLE 1.

Trends in Program Expenditures (Billions of 1990 Dollars) ${ }^{a}$

\begin{tabular}{|c|c|c|c|}
\hline Program & 1975 & 1980 & 1990 \\
\hline \multicolumn{4}{|l|}{ Cash Transfers } \\
\hline \multicolumn{4}{|l|}{$\overline{\mathrm{AFDC}}$} \\
\hline Total & 20.4 & 19.0 & 18.5 \\
\hline Federal only & 11.2 & 10.2 & 10.1 \\
\hline \multicolumn{4}{|l|}{ Earned income tax credit } \\
\hline Total & 3.2 & 3.2 & 6.9 \\
\hline Refunded portion of credit & 2.2 & 2.2 & 5.3 \\
\hline \multicolumn{4}{|l|}{ Earmarked Transfers } \\
\hline Food stamps & $10.2^{\mathrm{b}}$ & 13.8 & 15.1 \\
\hline Housing assistance & $6.3^{\mathrm{d}}$ & 8.6 & 10.6 \\
\hline \multicolumn{4}{|l|}{ Targeted Transfers } \\
\hline \multicolumn{4}{|l|}{ Medicaid } \\
\hline Total & 30.6 & 40.9 & 72.5 \\
\hline Federal only & 17.2 & 23.2 & 41.1 \\
\hline To dependent children & 5.4 & $5.1^{\mathrm{c}}$ & 9.1 \\
\hline $\begin{array}{l}\text { To adults in families with } \\
\text { dependent children }\end{array}$ & 5.1 & $5.5^{c}$ & 8.6 \\
\hline WIC & $0.6^{\mathrm{d}}$ & 0.7 & 2.1 \\
\hline School Lunch & $4.5^{\mathrm{d}}$ & 4.8 & 3.7 \\
\hline Head Start & 1.0 & 1.1 & 1.6 \\
\hline
\end{tabular}

aThese figures were taken from U.S. House of Representatives (1992), pages 654, 1019, 1616, 1651, 1680, 1684, 1689, and 1695.

bThe figure for 1975 includes administrative costs; the figures for 1980 and 1990 do not.

'These figures are for 1981.

${ }^{\mathrm{d}}$ These figures are for 1977.

penditures in each of the three categories, and Table 1 gives the amounts spent in 1975, 1980, and 1990. Table 2 provides information about caseloads in these three years. The rest of this section provides background information about the programs described in these tables.

2.1.1 Cash Transfers As shown in Figure 2 and Table 1, cash transfers can be divided into expenditures on AFDC and outlays under the Earned Income Tax Credit. AFDC was originally authorized under the Social Security Act of 1935 as a federal-state matching entitlement program that would provide assistance to fatherless children. ${ }^{4}$ As of Octo-

${ }^{4}$ The fact that it is an entitlement program means that anyone who meets the eligibility criteria is entitled to receive benefits. 
TABLE 2.

Caseloads for Eight Large Federal Programs (Millions).

\begin{tabular}{lcrr}
\hline Program & 1975 & 1980 & 1990 \\
\hline Cash Transfers & & & \\
AFDC & & & \\
$\quad$ Total recipients & 11.1 & 10.6 & 11.2 \\
$\quad$ Child recipients & 8.0 & 7.3 & 7.6 \\
Earned income tax credit & 6.2 & 7.0 & 13.3 \\
(total families) & & & \\
Earmarked Transfers & 16.3 & 19.2 & 20.2 \\
Food stamps (total recipients) & $3.2^{\mathrm{a}}$ & 4.0 & 5.4 \\
Housing assistance (total & & & \\
households) & & & \\
Targeted Transfers & & & \\
Medicaid & 22.0 & 21.6 & 25.3 \\
$\quad$ Total recipients & 9.6 & 9.3 & 11.2 \\
$\quad$ Child recipients & & & \\
WIC & $.2^{\mathrm{a}}$ & .4 & 1.0 \\
$\quad$ Number of women & .2 & .5 & 1.4 \\
$\quad$ Number of infants & .5 & 1.0 & 2.1 \\
$\quad$ Number of children & & & \\
School Lunch & $26.3^{\mathrm{a}}$ & 26.6 & 12.8 \\
$\quad$ Number with any meals & 10.5 & 10.0 & 10.3 \\
$\quad$ Number with free meals & 0.4 & 0.4 & 0.6 \\
Head Start & & & \\
\hline
\end{tabular}

aThese figures are for 1977.

ber 1, 1990, states are also required to offer an AFDC Unemployed Parent (AFDC-UP) program to two-parent families in which the principle earner is unemployed. ${ }^{5}$

AFDC is administered at the state level within federal guidelinesstates choose the need and payment standards that determine eligibility, set income and asset limits, and choose benefit levels. As a result, program characteristics vary widely from state to state. For example, as of January 1991, the maximum monthly AFDC grant for a one-parent family of four persons varied from $\$ 124$ in Alabama to $\$ 891$ in Alaska. By way of comparison, the federal poverty line for a family of four persons was $\$ 13,942$. On average the federal government pays 54 percent of benefit costs, as shown in Table 1 .

Figure 2 shows that expenditures on the AFDC program have been

${ }_{5}^{5}$ Only 5 percent of AFDC families qualified under this program in 1990. 
declining gradually over time. In view of the fact that the maximum AFDC benefit for a family of four in the median state fell by 33 percent between 1975 and 1990, it is remarkable that total expenditures have not fallen further. Since two, two-person families are more expensive than a single four-person family, these figures may reflect a shift in the composition of the caseload toward smaller families.

Table 1 shows that the slack in AFDC growth has been taken up by growth in expenditures on the Earned Income Tax Credit (EITC), which doubled between 1975 and 1990. Table 2 shows that the growth in expenditures was accompanied by a doubling of the caseload over the same period. The EITC was introduced in 1975 as a means of granting tax relief to low-income taxpayers. In 1992, the maximum EITC was $\$ 1,324$ for taxpayers with one qualifying child and $\$ 1,384$ for taxpayers with any additional qualifying children. The EITC begins to be phased out for taxpayers with adjusted gross income (AGI) above $\$ 11,840$ and is completely phased out for taxpayers with AGI greater than $\$ 22,370$.

Because it is administered through the tax system, the EITC is not usually viewed as a welfare program. However, unlike most tax credits, the EITC is "refundable," that is, if the amount of the credit exceeds the taxpayer's federal income tax liability, then the difference is refunded. Table 1 shows that in fact most EITC expenditures were outlays of this kind rather than foregone tax dollars. The EITC differs from traditional cash welfare programs primarily because the majority of recipients work, and benefits are available to all kinds of families.

\subsubsection{Earmarked Programs As discussed above, expenditures on ear-} marked programs can be divided into expenditures on the Food Stamp Program (FSP) and outlays for housing assistance. The Food Stamp Program grew out of efforts to transfer surplus agricultural commodities to the needy during the Great Depression. These programs had been formalized and extended to all counties by 1973 (Clarkson, 1975). Food stamps are issued in the form of booklets of coupons that may be used to purchase all foods except alcohol, tobacco, and hot foods "intended for immediate consumption." In contrast to AFDC, food stamps are available to all families who meet federally determined income-eligibility requirements, though AFDC recipients are automatically eligible. Interactions between the FSP and AFDC provide the only source of state-to-state variation in food stamp benefits-FSP income is reduced by $\$ .30$ for every dollar of countable income (including AFDC benefits), once certain disregards are applied. ${ }^{6}$ 


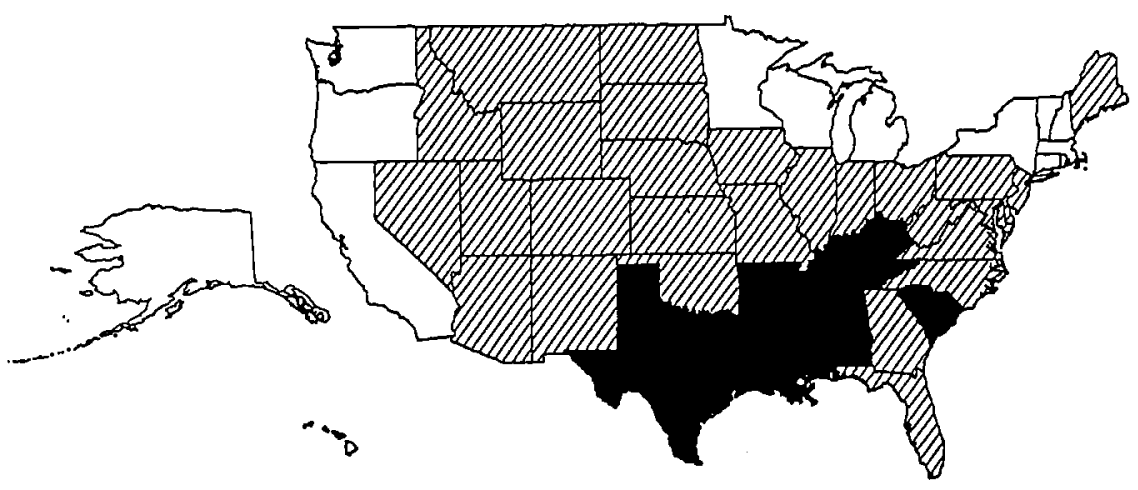

$40-688$
$80-788$
$80 \%+$

- Combined family benefit in $1 / 92$ as a percent of tho 1991 poverty threshold for a family of three. Sourco: U.S. House of Representatives (1992)

FIGURE 3. Maximum Combined AFDC and Food Stamp Benefit As a Percentage of Poverty.

Table 1 indicates that expenditures on the Food Stamp Program grew by 50 percent between 1975 and 1990, whereas Table 2 shows that caseloads rose only 25 percent. Hence, the increased generosity of food stamp benefits made up part of the loss in cash transfers for AFDC households. However, Figure 3 illustrates the fact that in 1992, even combined AFDC and food stamp benefits were not high enough to bring families up to the poverty level in most states.

Housing assistance has been provided since 1937 under the auspices of the Department of Housing and Urban Development (HUD). In contrast to AFDC and food stamps, housing assistance is not an entitlement: when funds allocated to the program run out, people who are eligible must be placed on a waiting list. It is estimated that about half of federal expenditures on housing assistance directly benefits children and that the elderly are the other large group of beneficiaries. The federal government offers mortgage assistance to low-income rural households, but most expenditures are on rental assistance programs.

The major forms of rental assistance are: 1) low-rent public housing, 2) Section 8 new construction/substantial rehabilitation, and 3) Section 8 existing housing. Low-rent public housing is what most people think of as "public housing." The Section 8 programs were established by the Housing and Community Development Act of 1974. Under the new construction/rehabilitation part of the program, the federal government subsidizes the rents of apartments brought into the stock by private 
developers. The Section 8 existing housing program provides rent subsidies to families who find an apartment of their own choosing, as long as the rent is below the "Fair Market Rent" established by HUD, and the unit meets minimum quality standards. Rental assistance typically reduces a family's rental payments to 30 percent of its income, after deductions for certain expenses are taken into account.

The Congressional Budget Office estimates that since 1982, over two thirds of new authorizations for rental housing assistance were for Section 8 programs (Pedone, 1988). The main rationale for this shift in policy is that it is cheaper to house a family in an existing unit under a voucher program than it is to build new public housing units (Apgar, 1990). Hence, more families can be served for the same budget outlay. Tables 1 and 2 show that both outlays on housing assistance and the caseload grew by roughly 66 percent between 1975 and 1990 .

2.1.3 Services Targeted Directly to Children Finally, turning to services targeted directly to children, Figure 2 indicates that the largest program of this kind is Medicaid, which provides health insurance to eligible poor families and to the aged, blind, and disabled. It was created in 1966 as a federal-state matching entitlement with the stated goal of eliminating financial barriers to medical care. Table 1 shows that expenditures on children account for a relatively small share of total Medicaid expenditures: the average expenditure on an AFDC child is $\$ 682$ compared to $\$ 5928$ for an aged person and $\$ 1290$ for an AFDC adult (U.S. House of Representatives, 1991). Notwithstanding children's relatively small share of Medicaid expenditures, Medicaid is the single most important health insurance program for poor children, accounting for over 55 percent of public expenditures on child health.

States are required to offer Medicaid coverage to AFDC recipients and to AFDC-UP families, and until recent extensions of coverage to other groups, there was a very close linkage between AFDC recipiency and Medicaid eligibility. However, evidence that many children and pregnant women were not receiving adequate preventive care led Congress to begin extending Medicaid coverage for pregnant women and children in 1984. States are now required to cover all pregnant women and children under six with family income less than 133 percent of the federal poverty line, regardless of family structure. ${ }^{7}$ As of July 1, 1991, states were also required to cover all children born after September 30, 1983, whose family incomes were less than 100 percent of the federal poverty line.

7 The coverage of pregnant women is limited to services related to the pregnancy. 
Tables 1 and 2 show that expenditures on children under the Medicaid program have risen dramatically since 1975, in spite of the slow growth in caseloads. This increase in Medicaid costs reflects an increase in the cost per visit that is also occurring in the non-Medicaid population (Newhouse, 1992). The relatively stagnant caseload may reflect low take-up rates among newly eligible children.

Other large programs that target services directly to children include school nutrition programs, WIC, and Head Start. ${ }^{8}$ Figure 2 indicates that relative to the growth in expenditures on earmarked programs and on Medicaid, there has been only modest growth in these three targeted programs: total expenditures on the National School Lunch Program, WIC, and Head Start increased only 20 percent between 1975 and 1990. However, Table 1 shows that this aggregate masks considerable variation in individual program trends. For example, expenditures on WIC tripled, while outlays on Head Start grew 60 percent, and expenditures on the NSLP actually fell 18 percent.

The federal government supports seven programs that provide meals or monthly food supplements to low-income children. The largest are the NSLP, the School Breakfast Program (SBP), and WIC. The NSLP and SBP are entitlements that operate by reimbursing schools for each meal served. WIC is funded by appropriation, and the size of each year's appropriation limits the number of people that can be served.

The NSLP was begun in 1946 in response to national concern about the fact that one third of World War II draftees suffered nutrition-related deficiencies that made them unfit for service. The NSLP is by far the largest of the child nutrition programs: in 1981, lunches were served to approximately 25 million students in 98 percent of the public schoolsenough to feed 60 percent of all students attending public schools (Radzikowski and Gale, 1984b). However, Table 2 shows that the total number of children served fell more than 50 percent by 1990 . School lunches are provided free to children with family incomes less than 130 percent of the federal poverty line, and are subsidized if the family income falls between 130 and 185 percent of the poverty line. Table 2 shows that the number of children receiving free lunches has remained relatively constant over time at about ten million, while the number receiving reduced-price meals declined 50 percent between 1975 and 1990, from twenty-seven to thirteen million.

The School Breakfast Program was instituted in 1966. It serves far fewer children than the lunch program: in 1981, about four million breakfasts were served in 33,000 schools, enough to feed about 10 percent of

${ }^{8}$ See Jones $(1990,1992)$ for further information about school nutrition programs and WIC. 
the public school student body. ${ }^{9}$ Participants in the SBP tend to be poorer than participants in the NSLP - with the result that the majority of school breakfasts have always been served free.

The WIC program provides nutritional counseling and food supplements to pregnant and lactating mothers and their infants as well as to low-income children up to age five. It is currently operated out of some 8,330 sites. The law requires that the WIC program provide foods containing protein, iron, calcium, vitamin $\mathrm{A}$, and vitamin $\mathrm{C}$. Food packages must be appropriately tailored to meet the needs of each category of recipient. ${ }^{10}$ In fiscal year 1991, the average monthly WIC package was valued at $\$ 31.67$.

WIC participants must have family incomes less than 185 percent of the poverty line (though states may set income thresholds as low as 100 percent of the poverty line) and must be certified as nutritionally "at risk" ${ }^{11}$ Participants must be recertified at intervals in order to continue in the program. Table 2 indicates that the WIC caseload shot up 400 percent between 1975 and 1990, far outstripping the increase in expenditures discussed above. WIC currently serves an estimated 60 percent of those eligible. According to the Congressional Budget Office, it would have cost $\$ 3.75$ billion, or 44 percent more than that year's appropriation, to serve all those who were eligible in 1992.

Head Start is a federal-local, matching grant program that aims to improve the learning skills, social skills, and health status of poor children so that they can begin schooling on an equal footing with their more advantaged peers. Federal guidelines require that 90 percent of the children served be from families with incomes below the federal poverty line. Given that there are over 1,300 Head Start programs (Hayes et al., 1990), all administered at a local level, there is a great deal of variation in program content.

Begun in 1964 as part of President Johnson's "War on Poverty," Head Start is one element of that program that has enjoyed great public and bipartisan support. Former President Bush and President Clinton both pledged to increase federal funding to serve all eligible children. In 1992, 622,000 children, roughly 28 percent of eligible three to five year olds, were served at a cost of $\$ 2.2$ billion (Stewart, 1992). Table 2 shows that

\footnotetext{
9 These numbers have remained relatively constant over time.
}

10 The categories are children zero to three months of age, four to twelve months, women and children with special dietary needs, children from one to five, pregnant and nursing mothers, and postpartum non-nursing mothers.

${ }^{11}$ Evaluation of WIC is complicated by the fact that providers do not use uniform criteria for certifying nutritional risk. 
this represents an increase in the caseload of 69 percent between 1975 and 1990.

In summary, cash transfers are being restricted increasingly to parents who work. Parents who do not work are receiving an increasing proportion of their assistance in the form of in-kind benefits. Only a relatively small share of these benefits, however, are in the form of specific services provided directly to children. The lion's share goes to families in the form of certificates that must be spent on food or housing.

\subsection{Measures of Child Well-Being}

Despite the fact that the programs discussed above are designed to benefit children, remarkably little research has gone into assessing the direct effects on child well-being. Much of the difficulty lies in finding data sets with information about both welfare participation and child outcomes. Ideally, one would like to examine a range of outcomes since the effects of participation are likely to be complex. For example, while Medicaid participation might be expected to improve a child's health, it may also have positive effects on schooling attainment if poor health would tend to impair a child's performance. This section describes the three classes of outcomes that are the focus of this review: measures of health, measures of cognition and schooling attainment, and measures of long-run social competence.

2.2.1 Measures of Health Status Infant and child mortality rates are perhaps the most objective and least controversial measures of children's health status. The infant mortality rate is defined as the number of babies born alive who die before reaching age one. At 10 per 1,000, the U.S. infant mortality rate is higher than that of any other industrialized country, and African-American rates are twice as high as white rates (Danzinger and Stern, 1990). A closely related measure of infant health is birth weight. In 1980, infants less than 2,500 grams accounted for less than 7 percent of all births, but 60 percent of infant deaths (U.S. House of Representatives, 1992). Gestational age is also used as a measure of neonatal health, but is subject to a great deal more measurement error than birth weight.

Height-for-age is an anthropometric measure of the health and nutritional status of older children (for babies the equivalent measure is length-for-age). Physical anthropologists have concluded that ethnic differentials in these measures are relatively minor for young children, although they become more important after puberty. Because growth varies systematically with age and gender, heights are usually standard- 
ized using guidelines from the National Center for Health Statistics. ${ }^{12}$ The incidence of low height-for-age (stunting) is much greater among poor than among nonpoor children. For example, a 1983 study carried out by the Massachusetts Department of Health found that 9.8 percent of preschool children in Massachusetts had a height-for-age below the fifth percentile of the NCHS standards (Massachusetts Department of Health, 1983).

Nutritional status can also be assessed using information about the nutrients available in a family's usual diet, individual nutrient intakes, or biochemical tests. Low-income American children are at risk of iron and zinc deficiencies and often lack vitamin C. For example, Devaney, Haines, and Moffitt (1989) found that 20.6 percent of one- to two-yearold children in low-income households suffered iron anemia compared to 6.7 percent of one- to two-year-olds from higher income households. These deficiencies have been linked to growth retardation, lethargy, impaired immune status, and learning problems.

A third class of measures deals with the child's utilization of medical services. Measures such as the number of doctor visits for illness are problematic since they are affected both by illness and by the propensity to utilize care. Visits for preventive care provide clearer measures of utilization. Prenatal care is an important type of preventive care. When adequate in terms of timely initiation and total number of visits, it can significantly reduce the risk of low birth weight and infant mortality (Institute of Medicine, 1985).

2.2.2 Test Scores and Schooling Attainment Academic achievement is a crucial determinant of a child's success in our society: each additional year of high school is estimated to raise future wages by as much as 8 percent. ${ }^{13}$ It is not surprising, then, that many tests of academic achievement have been developed. These tests are controversial: African Americans obtain poorer scores than whites, and depending on the test, girls sometimes outperform boys or vice versa. Ultimately, after controlling for measures of background, it is not clear that these tests are good predictors of a child's academic success at all. More direct indications of academic attainment include whether the child has ever taken remedial courses or failed to advance in grade. There is a great deal of evidence which suggests that children who lag behind their peers even at early ages are at higher risk of eventually dropping out of high school (Ensminger and Slusarcick, 1992).

12 See Currie and Thomas (1993b) for further details.

13 See Angrist (1990) for a recent estimate. 
2.2.3 Longer-Term Measures The ultimate measure of a welfare program's success is the long-run situation of children whose families participated. Are they less likely to become pregnant as teenagers, to be unemployed, or ultimately to have their own children participate in welfare programs? It has proven extremely difficult to answer this question because it is hard to sort out the effects of welfare participation from the effects of family background and community characteristics.

\section{DO CASH TRANSFERS BENEFIT CHILDREN?}

\subsection{Effects of AFDC}

Most research about the effects of AFDC on children focuses on the question of whether daughters of women who participate in AFDC are themselves more likely to participate (cf. Gottschalk, 1990). Critics of the welfare system point to the intergenerational transmission of welfare dependency as evidence that parental welfare participation actually harms poor children by affecting their aspirations (cf. Murray, 1984). However, this argument overlooks the fact that women whose mothers were on AFDC are more likely than other women to be on AFDC simply because the children of the poor are more likely to be poor.

Zimmerman and Levine (1993) test the hypothesis that AFDC has no additional negative effect using data from the original National Longitudinal Surveys and the National Longitudinal Survey of Youth. They regress the daughter's participation in AFDC on measures of maternal participation, maternal income, and other background variables. Since both maternal AFDC participation and income are to some extent choices and may be measured with error, they propose the following instrumental variables (IV) technique: instrument AFDC participation using maximum benefit levels in each state and instrument income using the Duncan index of the mother's and father's occupations. ${ }^{14}$ They find that maternal AFDC participation has no statistically significant effect on the daughter's probability of participation, once maternal income is controlled for.

This IV scheme implicitly assumes that women do not migrate in response to AFDC benefits and that occupational choices are predetermined to a greater extent than incomes are. The first assumption is reasonable in light of empirical evidence that migration flows in response to benefit levels are very small (Moffitt, 1992). The second is perhaps less defensible. Still, Zimmerman and Levine's paper is the first

${ }_{14}$ The Duncan index is a linear combination of the median earnings and education associated with an individual's occupation. 
to attempt to instrument both participation and income in a reasonable way, and it suggests that poverty, not maternal welfare receipt, creates welfare mothers.

These results suggest that maternal welfare participation does not encourage teenage pregnancy and child-bearing. ${ }^{15}$ Although the teen birthrate has fallen over time (from 90 births per 1,000 in 1955 to 54 per 1,000 in 1988), out-of-wedlock births to teenagers increased from 15.1 to 37 per 1,000 women aged 15 to 19 over the same period (U.S. Department of Health and Human Services, various years). The fact that the rate of out-of-wedlock pregnancy has increased while the AFDC benefit level has continued to fall also indicates that there is no simple relationship between the two. Studies that have examined this question directly reach the same conclusion. For example, neither Moore and Caldwell (1977) nor Ellwood and Bane (1985) were able to find any consistent effect of state benefit levels on the probability of a teen pregnancy. ${ }^{16}$

There has been comparatively little research linking maternal AFDC participation to other child outcomes, but the empirical issues are the same. First, it is necessary to control for some measure of income as well as for AFDC status; otherwise the estimated effects of participation are likely to reflect the relative poverty of AFDC mothers. Second, within the group of poor women, one would like to control for the endogeneity of AFDC status. Blank and Ruggles (1993) show that only 60 percent of eligible women actually take up welfare benefits. Those who do are likely to differ from those who do not in many unobservable respects.

Hill and O'Neill (1992) find that, when IV methods are used to control for AFDC status, AFDC participation has no effect on children's scores on a standardized test of vocabulary, conditional on income. They do not control for the potential endogeneity of income. Currie and Cole (1993) use data from the 1979 to 1988 waves of the National Longitudinal Survey of Youth (NLSY) to examine the effect of AFDC participation during pregnancy on the utilization of prenatal care and birth weight. They attempt to control for selection into the AFDC program in two ways. First, they instrument AFDC participation using state-level varia-

15 Concern is often expressed that AFDC has contributed to the problem by undermining family values-by supporting single parenthood and allowing teenagers to set up housekeeping on their own once they have a child. The Family Support Act of 1988 eliminated some of the perverse incentives of the system by requiring all states to establish AFDC-UP programs and to make more strenuous efforts to establish paternity and extract childsupport payments from fathers.

16 Moore and Caldwell also find no effect for the rate at which AFDC applications were accepted. However, they did find that the availability of family planning clinics had a significant negative effect on the probability of teen pregnancy. 
tion in program characteristics. Second, they focus on the sample of children who are siblings and estimate models that control for fixed effects associated with each mother. This procedure "differences out" any fixed maternal characteristics (such as lack of education) associated with program participation. Finally, they control for a measure of "permanent income" on the grounds that this is less subject to endogeneity bias than a measure of contemporaneous income. They do not find any significant effect of AFDC participation on birth weight. Together, these studies suggest that income from AFDC has much the same effect on children as family income from any other source.

3.1.1 The Effects of the EITC If it is difficult to identify the effects of cash transfers under the AFDC, the problems involved in identifying the effects of the EITC are even more formidable. The fundamental difficulty is that the amount of the credit depends only on the parents' earnings, and earnings are likely to reflect many unobserved factors relevant to child well-being. However, the EITC is in many respects similar to the "Negative Income Tax" (NIT), an income-guarantee program that was subjected to exhaustive scrutiny through a number of large-scale social experiments, although it was never implemented. This section draws the parallels between the two programs, and discusses what can be learned about the effects of cash transfers from the NIT experiments.

Under an NIT, a family who earns no income is guaranteed a minimum level of income, $G$. Families with earnings $Y$ receive a payment $D$, where $D=G-t_{1} Y$. The quantity $B=G / t_{1}$ is referred to as the break-even level of income, since workers who earn more than $B$ receive no payments. If income is equal to the wage multiplied by hours worked, and workers face a tax rate $t$, then workers on the NIT earn $w\left(1-t-t_{1}\right)$ for every hour of work, whereas workers with incomes above $B$ earn $w(1-$ t). That is, workers on the NIT face a higher implicit tax rate than other workers. Hence, both the EITC and the NIT work through the tax system to increase the level and reduce the variance of income among the poor.

In order to investigate whether the NIT created significant work disincentives, the Office of Economic Opportunity under President Nixon authorized four large-scale social experiments. The first experiment, in New Jersey and Pennsylvania, lasted from 1968 until 1972 and involved 1,357 low-income couples. A rural experiment took place in lowa and North Carolina from 1969 to 1973 and included 809 low-income rural families. A third experiment was conducted in Gary, Indiana, between 1971 and 1974 and was composed of 1,780 African-American households, 59 percent of them female-headed. The largest experiment, which 
affected 4,800 families, was conducted in Seattle and Denver from 1971 to 1982 .

The NIT experiments represented the first large-scale attempt to investigate social policy using a treatment-and-control design with random assignment. Treatments received an income-guarantee level and a tax rate. The guarantees were usually expressed as a percentage of the federal poverty line, and ranged from 50 to 250 percent. The average payments in the Seattle/Denver experiment, for example, ranged from $\$ 919$ to $\$ 2,031$ (1972 dollars), depending on the treatment group. By way of comparison, the poverty line for a family of three in 1972 was $\$ 3,099$. The NIT experiments provide a unique opportunity to assess the effects of income transfers per se on the well-being of children in poor families.

In principle, the use of random assignment overcomes the problem of selection that is ubiquitous in the program evaluation literature, and allows the effects of the program to be identified through a simple comparison of treatments and controls. However, the NIT experiment was flawed in two respects. First, treatments and controls were randomly assigned only within income categories. Hence, the cell sizes available for treatment/control comparisons are very small. Second, controls were much more likely to leave the experiment than treatments. These two problems mean that much of the NIT data has been analyzed using conventional nonexperimental methods and that the results are sensitive to the way problems of nonrandom selection into treatment groups and attrition are handled (Ashenfelter and Plant, 1990).

These problems may account for inconsistent findings across experimental populations and for econometric estimates that are at odds with those derived from simple comparisons of treatments and controls. For example, Kehrer and Wolin (1979) find that the mean birth weight of infants born to the treatment group in the Gary experiment was actually lower than the birth weight of the controls. Yet estimates from their structural model suggests that the infants of treatments had higher birth weights in nine out of twelve maternal age groups. O'Conner, Madden, and Pringle (1976) examined the effect of the NIT on child nutrition using data from the rural experiment. Among subjects in North Carolina, they found positive and significant treatment effects on intakes of total calories, calcium, phosphorus, iron, riboflavin, and vitamin C. However, the treatment did not appear to have any significant effect in Iowa, a finding that the authors attribute to the relative poverty of the North Carolina sample.

The results from the rural and Gary experiments also have been used to examine the effect of the NIT on schooling attainment. Maynard and Crawford (1976) found that elementary school children from NIT fami- 
TABLE 3.

School Performance in the Rural Experiment: Differences between Treatments and Controls as a Percent of Control Mean.

\begin{tabular}{lccccr}
\hline & \multicolumn{2}{c}{ Grades 2-8 } & & \multicolumn{2}{c}{ Grades 9-12 } \\
\cline { 2 - 3 } Measure & North & & North & \\
& Carolina & Iowa & & Carolina & Iowa \\
\hline Days absent & $-30^{* *}$ & -20.0 & & 3 & -17 \\
Academic Grades & $6^{*}$ & -5.0 & & 4 & -5 \\
Achievement Tests & $19^{* *}$ & -18.8 & & n.e. & n.e. \\
(deviation from norm) & & & & \\
\hline
\end{tabular}

Source: Maynard and Crawford (1976). There were 847 children.

* Significant at the 90 percent level of confidence.

** Significant at the 95 percent level of confidence.

n.e. Not estimated due to lack of data.

lies in North Carolina showed statistically significant improvements in attendance, performance on standardized tests, and grades. However, there were no effects for older children or for elementary school children in Iowa. Their results are reproduced in Table 3. Once again, this pattern of results is attributed to the fact that the children in North Carolina were much more disadvantaged than those in lowa. Maynard and Murnane (1979) found that in the Gary experiment the NIT treatment had positive effects on the reading scores of younger children but that these effects were statistically significant only among children whose families had been in the program for three or more years.

Finally, in an analysis of data from the New Jersey experiment, Mallar (1977) found that teenagers whose parents were enrolled in an NIT plan were between 20 percent and 90 percent more likely to complete high school, depending on the parameters of the plan. This group also completed one-third to one-and-a-half more years of education than their counterparts in the control group. Venti (1984), however, found only an 11 percent increase in the probability of completing high school for youth in the Seattle/Denver experiment. This lower estimate seems more probable in view of the relatively short duration of the experiments, and the many long-term factors (such as achievement in early grades) that have been linked to educational attainment. These results also may be related to the fact that in all four experiments youths in treatment households were less likely to be employed than controls (Robins, 1985).

These studies suggest that the relatively large income transfers made to poor families under the NIT had a positive effect on the nutritional 
status and educational attainment of children, especially among the poorest families. However, the magnitudes vary so greatly from study to study that it is difficult to say how large these effects are. Perhaps unsurprisingly, studies of the consumption effects of the NIT also suggest that families spent much of the subsidy on goods that may not have been directly related to the well-being of their children. For example, the NIT appears to have had a negative effect on the labor supply of married women ${ }^{17}$ and positive effects on housing expenditures and purchases of consumer durables (Robins, 1985; Michael, 1978). The NIT may also have increased the probability of marital dissolution, although this finding remains controversial (cf. Cain and Wissoker, 1990; Hannan and Tuma, 1990).

\section{THE EFFECTIVENESS OF IN-KIND TRANSFERS}

\subsection{Earmarked Transfers}

4.1.1 Effects of the Food Stamp Program It would be surprising to find that the marginal propensity to consume food out of food stamp income differed from the marginal propensity to consume food out of cash income, because 85 to 90 percent of participating households have food expenditures that exceed the value of their FSP benefits. Two experimental "cashout" programs have suggested that food stamp income is treated exactly like cash income. However, one of these programs took place in Puerto Rico where there was a thriving black market in stamps before the cashout (Moffitt, 1989), and the other affected only elderly households (Blanchard, 1982). Hence it is not clear that the results of these experiments can be transferred to mainland families with children.

On the other hand, nonexperimental evaluations of the fungibility of food stamps among families with children are contaminated by the failure to properly control for the endogeneity of program participation. For example, Table 4 shows that FSP households purchase more nutritious food for home consumption than nonparticipating households, ${ }^{18}$ but it is not clear whether this is a cause or an effect of program participation. It might be the case that families who participate care more about nutrition. Because the FSP is federally administered, all geographic variation in benefits comes from interactions between the AFDC program and the FSP. Many researchers have tried to identify IV models by finding char-

17 No convincing evidence of a link between maternal employment and children's wellbeing has been found. See Blau and Grossberg (1990) and Desai et al. (1989).

18 These differences remain when observable characteristics of the household are controlled for. 
TABLE 4.

Household Nutrient Availability as a Percentage of the RDA for Persons Eating in the Households.

\begin{tabular}{lccc}
\hline Nutrient & $\begin{array}{c}\text { FSP Participants } \\
\text { (a) }\end{array}$ & $\begin{array}{c}\text { FSP Nonparticipants } \\
\text { (b) }\end{array}$ & $\begin{array}{r}\text { Difference } \\
(\mathrm{a}-\mathrm{b})\end{array}$ \\
\hline Food Energy & 139 & 121 & +18 \\
Protein & 232 & 203 & +29 \\
Calcium & 119 & 111 & +8 \\
Iron & 151 & 137 & +14 \\
Magnesium & 134 & 123 & +11 \\
Phosphorous & 202 & 183 & +19 \\
Vitamin A & 213 & 178 & +35 \\
Thiamin & 194 & 165 & +29 \\
Riboflavin & 204 & 180 & +24 \\
Vitamin B6 & 132 & 114 & +18 \\
Vitamin B12 & 235 & 191 & +44 \\
Vitamin C & 290 & 264 & +26 \\
\hline
\end{tabular}

Source: Fraker (1990b).

acteristics of families that affect program participation without affecting food expenditures. Fraker (1990b) provides a review of this literature.

Fraker (1990a) presents one of the few studies that attempts to use the geographic variation in FSP benefits to identify the effects of the program. He finds that in ordinary least squares (OLS) regressions, participation in the FSP has a positive effect on seven of sixteen nutrients examined. When he instruments using maximum FSP benefits as one of the instrumental variables, the standard errors rise but the point estimates stay relatively constant. This result suggests that positive and significant effects of the FSP may appear with greater variation in benefit levels or larger samples.

The results of Korenman and Miller (1992) are also inconclusive. They use data from the National Longitudinal Survey of Youth to examine the effect of FSP participation during pregnancy on birth weight, on the incidence of low birth weight, on gestational age, on the incidence of prematurity, and on the mother's weight gain during pregnancy. They find a statistically significant effect of participation on women with incomes less than 50 percent of the poverty line on birth weight of first-born children in OLS regressions. However, they find no effect for children of higher-birth order; nor do they find one when they control for unobserved characteristics of the mother using fixed effects models. They also report that the height-for-age of children whose families received food stamps in the year prior to the survey is significantly lower than that of other children. These 
results highlight the importance of controlling for unobserved heterogeneity when evaluating the efficacy of social programs.

There are two intriguing hypotheses that have been advanced to explain why food stamp income might have an effect on nutrient intakes different from that of cash income. First, it is possible that households view FSP benefits as a more permanent source of income than other sources. Second, women with children may have higher marginal propensities to purchase food than men, and the female head of household may have more control of food stamp coupons (which are likely to be issued in her name) than she has over the household's cash income. ${ }^{19}$ Neither theory has been subjected to an empirical test.

\subsubsection{Effects of Housing Assistance Deficient housing can pose a haz-} ard to children's health. Lead poisoning, for example, is three times more common among poor children than among nonpoor children and is directly related to housing conditions. The risk of accidental death is also three times higher for poor children, and some of this increased risk may stem from hazards in the home (Starfield, 1985). In 1989, 18 percent of poor households (2.2 million households) were in housing with severe or moderate physical problems, compared with 7 percent of nonpoor households. ${ }^{20}$ If housing assistance enables families in deficient housing to move to adequate housing, then it probably improves the physical well-being of children.

Nonetheless, little evidence is available on this question. A 1988 HUD study found that more than half of public-housing households were in projects that needed moderate to substantial rehabilitation just to meet HUD's own standards. The estimated cost of bringing these units up to standard would exceed $\$ 20$ billion (1986) (Lazere et al., 1991). Most voucher programs require families to locate a landlord willing to participate in the Section 8 program and to arrange inspections and repairs with the landlord within a fixed period of time. One case study of fiftysix single mothers in eastern Massachusetts in 1985 and 1986 found that after waiting an average of two years to receive a certificate, twenty-four women returned them unused because they were unable to find housing

19 Some circumstantial evidence pertinent to this hypothesis comes from the Washington State Welfare Reform Demonstration Program. AFDC recipients in demonstration counties had the option of choosing to receive their AFDC and food stamp benefits in the form of a single consolidated check rather than continuing to receive food stamp coupons. Over 20 percent of these women opted to continue receiving the coupons.

${ }^{20}$ Problems HUD classifies as severe include lack of basic plumbing facilities, serious heating breakdowns, and rat infestations. An example of a moderate deficiency is the use of unvented gas, oil, or kerosene heaters as primary heating equipment. 
that met program requirements within the allotted time (Mulroy, 1988). The remaining women were able to improve their housing situations. Data from the 1986 Freestanding Voucher Demonstration program indicates that 60 percent of eligible households participated and that 57 percent of the subsidy went toward increasing rental payments (Kennedy and Finkel, 1987). Hence, there is some evidence that voucher programs decrease the number of participating households living in substandard housing. ${ }^{21}$

Unaffordable housing can also have harmful effects on children, by squeezing family budgets. Standards set by federal law define affordable housing as housing that consumes no more than $30 \%$ of a household's "adjusted" income.22 In 1989, three quarters of poor households in the United States paid over 30 percent of their income for housing, and more than half spent over 50 percent (Lazere et al., 1991). Families on AFDC fare just as badly, because in all but seven states, the maximum AFDC benefit for a family of three is less than HUD's estimate of the "Fair Market Rent" for a two-bedroom apartment. For families in these circumstances, receiving housing assistance can effectively double the family's cash income. Meyer et al. (1993) report that among low-income children attending a Boston clinic, those living in public housing or receiving rent subsidies are significantly less likely to suffer from iron anemia. This evidence is consistent with the evidence from the NIT experiments, suggesting that large cash transfers can improve the nutritional status of the poorest children.

Finally, in principle, housing assistance can affect children by influencing the parents' choice of neighborhoods and schools. For example, Johnson (1986) found that recipients of housing allowances frequently moved to better neighborhoods, although they did not usually move to less segregated ones. Yet, it is very difficult to identify the effects of neighborhoods and schools because any relationship observed between neighborhood characteristics and individual outcomes could reflect the characteristics of the family or one of its members that drew them to the neighborhood in the first place.

The Gautreaux program provides a "natural experiment" that sheds light on this issue. It grew out of a lawsuit filed in 1966 against the Chicago Housing Authority and HUD on behalf of public-housing resi-

21 Contemporary voucher programs seem to have larger effects on rental payments than do subsidies offered to families under the Experimental Housing Program. See Apgar (1990) for a discussion.

22 Adjustments include deductions for dependent children, handicapped or elderly family members, and for excessive health or child-care costs. 
dents. The suit charged that the Chicago low-rent, public-housing program had been administered in a racially discriminatory manner. A consent decree established by the Supreme Court in 1976 created a unique demonstration program with the aim of reducing segregation in Chicago's public housing.

Under the program, residents in public housing projects can apply for Section 8 housing certificates and move to private apartments. Some apartments are in predominantly white suburbs, whereas others are in the inner city. Although the persons admitted to the program are not a random sample of public-housing residents, ${ }^{23}$ the program assigns apartments in a more or less random manner; the apartment an applicant is offered depends on what is available when the applicant reaches the top of the waiting list. Very few applicants turn down an apartment, because they are unlikely to be offered another if they do. Hence, differences in outcomes between applicants assigned to the suburbs and those assigned to the city are likely to reflect true neighborhood effects.

Rosenbaum (1986) found that children of participants who moved to the suburbs attended schools that were superior in terms of smaller class sizes and satisfaction with teachers and courses. On average, these children had better attitudes toward school and suffered no permanent decline in grades or attendance. Some children, however, had trouble meeting higher academic standards in the suburbs and were placed in lower grades, lower tracks, or remedial education.

The children in the original study were re-interviewed 7 years later (Rosenbaum, 1992). Unfortunately, because only 59\% (107) of the original sample children could be located, the estimated program effects may be biased if there was differential attrition from the two groups. Still, the results are striking: children who had moved to the suburbs were 15 percent less likely to have dropped out of school, 16 percent more likely to be in a college-track program, and 34 percent more likely to be employed than those who had moved within the inner city. All of these differences were statistically significant at the 90 percent level of confidence. These findings suggest that voucher programs can have a positive effect on the life chances of children if they enable families to find housing in better neighborhoods. On the other hand, they suggest that the disamenities associated with large public housing projects may have significant negative effects. HUD is currently planning several housing

23 Applicants are screened to make sure that they have paid their rent regularly, and that they have adequate housekeeping abilities. The program does not serve families with more than four children because few large housing units are available in the suburbs. In addition, the act of applying for an apartment in an unknown location may indicate that a person is strongly motivated to improve his or her circumstances. 
experiments that will be based on the Gautreaux model. ${ }^{24}$ An experimental evaluation that took care to minimize attrition could shed great light on the possible beneficial effects of housing vouchers.

\subsection{In-Kind Programs That Target Specific Services to Children}

4.2.1 Medicaid The introduction of Medicaid in 1966 coincided with decreases in infant mortality, increases in hospitalization rates for poor children, and an increase in the frequency of doctor visits to poor, relative to nonpoor, children (Danzinger and Stern, 1990; Starfield, 1985). The timing of the decrease in infant mortality is suggestive but not totally compelling evidence of a beneficial effect of Medicaid on the health of poor children, because infant mortality periodically falls sharply in response to technological change. ${ }^{25}$ Time-series evidence regarding the number of doctor visits is also difficult to interpret, because visits for illness reflect both morbidity and utilization of care. This section reviews recent evidence that Medicaid coverage improves access to preventive care and that the gains are related to declines in the prevalence of low birth weight and infant mortality.

Currie and Thomas (1993a) use the 1986 and 1988 waves of the National Longitudinal Survey's Child Mother file (NLSCM) to examine the relationship between insurance coverage and whether a child had a routine checkup in the last six months. As discussed above, visits for preventive care are a more satisfactory measure of utilization than the total number of doctor visits because they do not depend on illness. In each year, mothers were asked whether their child's health care was covered by either Medicaid or private insurance. The ability to distinguish between Medicaid and private insurance is useful because children with private health-insurance coverage tend to be better off in observable (and presumably also in unobservable) dimensions than children with Medicaid coverage. Hence, if Medicaid has a stronger effect on the utilization of preventive care than private health-insurance coverage, then the evidence is strong that the estimated effect reflects insurance coverage rather than omitted characteristics correlated with selection into the Medicaid programs.

Ordinary least squares estimates of the probability that a child had a routine checkup are shown in Table 5. These regressions include dummy variables for both Medicaid coverage and private health-insurance cover-

24 Personal communication with Susan Mayer, Department of Sociology, Northwestern University.

${ }^{25}$ For example, up to half of the decline in infant mortality between 1989 and 1990 may be due to the introduction of surfactant therapy - a treatment for premature infants suffering Respiratory Distress Syndrome (Horbar, 1993). 
TABLE 5.

OLS Estimates of the Effects of Medicaid and Private Health Insurance on the Probability of a Routine Checkup.

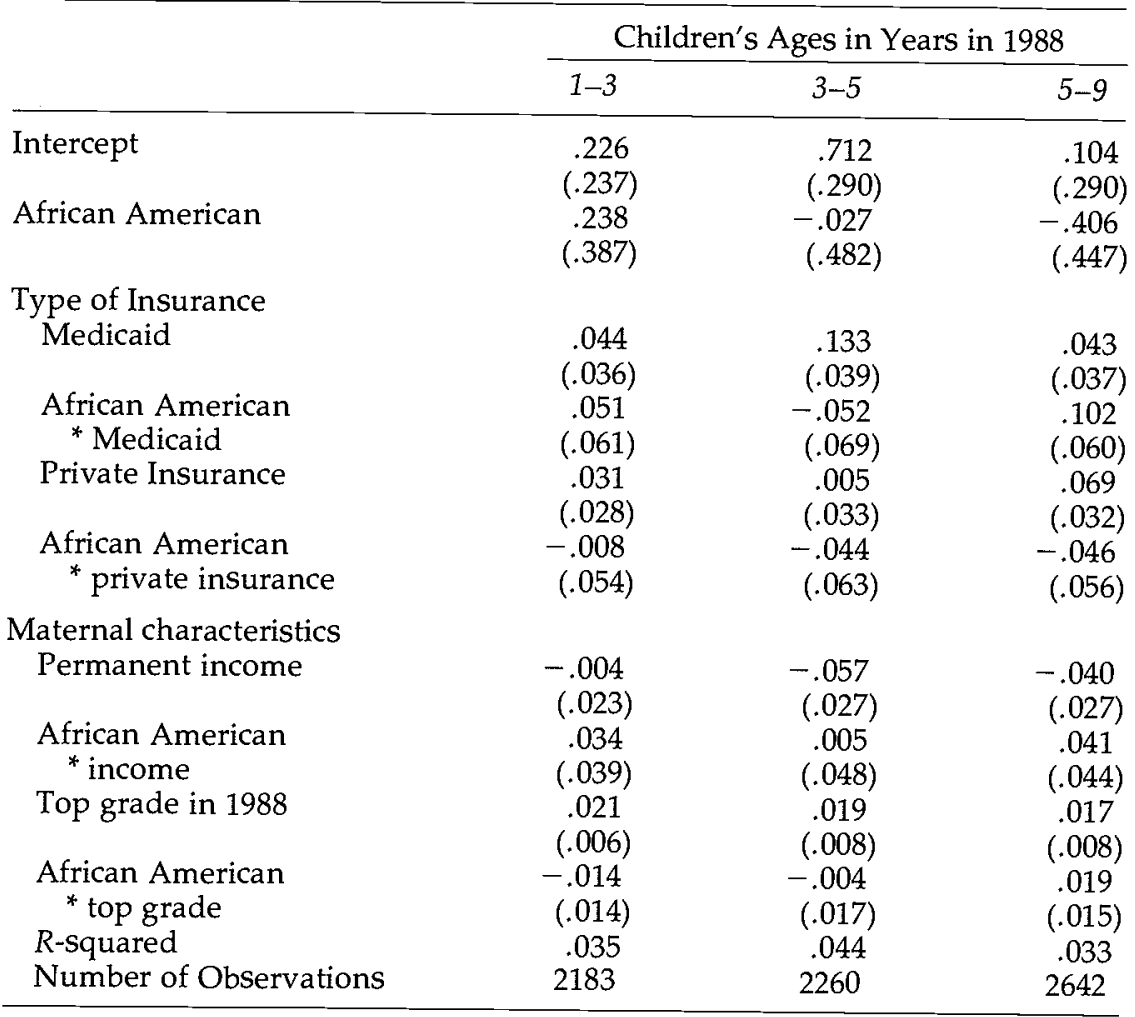

Source: Currie and Thomas (1993a).

Notes: Standard errors in parentheses. All regressions also included: The mother's Armed Forces Qualification Test score; an indicator equal to one if she was in the poverty sample; an indicator equal to one if the mother lived in an urban area at age fourteen; the child's gender; county income per capita; the number of physicians per 1,000 state residents; the number of hospital beds per 1,000 state residents; the state infant mortality rates; dummy variables for residence in the Northeast, South, or West; an indicator equal to one if the data came from the 1986 survey and zero otherwise; and interactions of all these variables with the indicator for African Americans. Since observations from both the 1986 and 1988 NLSCM surveys have been pooled, a control for the earlier survey was included to allow for possible differences between the two waves.

age. The excluded category is the absence of insurance. The models also include a full set of interactions with an indicator equal to one if the child is African American. This specification is equivalent to estimating separate models for whites and African Americans, but allows a ready comparison of the effects of insurance coverage on the two groups. The complete set of control variables is listed in the table notes. 
Medicaid coverage is estimated to increase the probability of a routine checkup among white children three to five years of age by 13 percent. In contrast, African-American children on Medicaid are between 8 percent and 15 percent more likely to receive a checkup at all ages. On the other hand, there are no statistically significant differences between children with private health-insurance coverage and those without healthinsurance coverage, except among white children of school age. This result may reflect the fact that many private insurance policies do not cover preventive pediatric care (Mitchell and Schurman, 1984), so that children may not receive regular preventive care until they enter the school system.

These OLS models do not control for selection into the program. It is possible to do better using these data, because in many cases, there are repeated measures of the same child. Currie and Thomas (1993a) also estimate conditional logit models that include fixed effects for each child. These models control for any unobserved characteristics of the child (such as the education of the mother or innate sickliness) that may be correlated with program participation and examine the effects of changes in Medicaid and private-insurance status on the probability of receiving a checkup. The estimates are remarkably similar to the OLS estimates discussed above.

Another way to control for selection into the Medicaid program is to identify the effects of Medicaid using state-level variation in the coverage of pregnant women and children. As discussed in the first part, the federal government began expanding the Medicaid coverage of pregnant women and children beginning in 1984 . By January 1992, a uniform, minimum floor for coverage had been established that was two to three times higher than the floor that had existed in the average state only four years earlier. However, this floor was raised at very different rates in different states.

Currie and Gruber (1993) use data from The National Longitudinal Survey of Youth, Vital Statistics, and the Current Population Survey (CPS) to examine the impact of the Medicaid expansions on the usage of prenatal care, the incidence of low birth weight, and infant mortality. Using CPS data, they first construct two measures of the generosity of state Medicaid programs in each year. The first is the fraction of women aged fifteen to forty-four who would have been eligible for Medicaid had they become pregnant. The second measure controls for nonprogrammatic sources of heterogeneity between states by drawing a random sample of U.S. women in each year and calculating the percentage of them that would have been eligible under each state's rules. Using this second measure Currie and Gruber find evidence that a 20 percent in- 
crease in the fraction of women eligible for Medicaid would be associated with a 4 percent decrease in the probability that the initiation of prenatal care was delayed beyond the first trimester. Turning to statelevel data from vital statistics, they also find that the Medicaid expansions were associated with improvements in birth outcomes: a 20 percent increase in eligibility decreased the incidence of low birth weight and infant mortality by 2 percent and 7 percent respectively.

One caveat to these positive results is that early expansions of Medicaid coverage to poor women who had been ineligible for AFDC for reasons of family structure (e.g., single pregnant women without eligible children) had much greater effects on the incidence of low birth weight than later extensions of coverage to women with incomes between 100 percent and 185 percent of the poverty line. Their analysis of self-reported Medicaid coverage in the CPS suggests that many women in the latter group did not take up their new benefits.

4.2.2 WIC WIC is more interventionist than traditional welfare programs: eligibility is often determined by medical examinations and blood tests, and nutritional counseling is required. In addition, the types and even brands of foods that can be purchased using WIC coupons are strictly controlled. Many studies find that WIC has positive effects on the utilization of prenatal care and on measures of infant health, including birth weight, the incidence of low birth weight, gestational age, and infant mortality. ${ }^{26}$

Schramm (1985) and Devaney et al. (1990) examine the effects of WIC on the Medicaid costs of newborns. The results are of particular interest because they can be used to compare the costs and benefits of the WIC program. Schramm found that in 1980 a dollar spent on WIC reduced Medicaid costs in Missouri by approximately $\$ .80$ in the first thirty to forty-five days after birth. Devaney et al. examine Medicaid costs in the first sixty days after birth. Their study examined all Medicaid births in 1987 for Florida, Minnesota, North Carolina, and South Carolina, as well as births from January through June 1988 in Texas. The authors examine women covered by Medicaid, comparing those who were enrolled in WIC with those who were not. Limiting the study to Medicaid eligibles is likely to eliminate some but not all of the observed and unobserved differences between WIC participants and nonparticipants. The average costs for newborns and their mothers in the sixty days after birth ranged from $\$ 2,433$ to $\$ 3,822$, depending on the state. The reductions in Medicaid costs for newborns and their mothers that were associated with WIC

${ }^{26}$ See Devaney, Bilheimer, and Schore (1990) for a review. 
TABLE 6.

Estimated Benefit-Cost Ratios for WIC Participants.

\begin{tabular}{lccc}
\hline & $\begin{array}{c}\text { Estimated } \\
\text { savings in } \\
\text { Medicaid } \\
\text { costs }^{\mathrm{a}, \mathrm{b}}\end{array}$ & $\begin{array}{c}\text { Estimated } \\
\text { prenatal WIC } \\
\text { costs per } \\
\text { Participant }\end{array}$ & $\begin{array}{c}\text { Estimated } \\
\text { benefit }^{\text {cost ratios }}\end{array}$ \\
\hline $\begin{array}{l}\text { Florida } \\
\quad \text { Newborns and mothers }\end{array}$ & $\$ 347$ & $\$ 196$ & 1.77 \\
$\begin{array}{l}\text { Minnesota } \\
\quad \text { Newborns and mothers }\end{array}$ & $\$ 277$ & $\$ 151$ & 1.83 \\
$\begin{array}{l}\text { North Carolina } \\
\text { Newborns }\end{array}$ & $\$ 744$ & $\$ 191$ & 3.90 \\
$\quad$ Newborns and mothers & $\$ 598$ & $\$ 191$ & 3.13 \\
$\begin{array}{l}\text { South Carolinac } \\
\text { Newborns and mothers }\end{array}$ & $\$ 565$ & $\$ 232$ & 2.44 \\
$\begin{array}{l}\text { Texas } \\
\text { Newborns }\end{array}$ & $\$ 573$ & $\$ 202$ & 2.84 \\
Newborns and mothers & $\$ 493$ & $\$ 202$ & 2.44 \\
\hline
\end{tabular}

Source: Devaney, Bilheimer, and Schore (1990).

${ }^{a}$ Medicaid costs are from birth to sixty days after birth.

bAll estimates are statistically significant at the .01 level (two-tail test), except in Minnesota, where the estimate is statistically significant at the .07 level (two-tail test) and at the .03 level (one-tail test).

'Medicaid costs refer to hospital costs only.

participation ranged from $\$ 277$ to $\$ 598$. As Table 6 shows, the reductions in Medicaid costs more than offset the costs of providing WIC to these women.

Unfortunately, only two WIC studies, by Metcoff et al. (1985) and Caan et al. (1987), have used random assignment to generate a comparison group. Studies that do not use random assignment suffer from the fact that participants may differ from non-participants in unobserved ways. If WIC participants are in worse condition than nonparticipants because places are scarce and only the neediest are admitted into the program, then studies that compare WIC participants and nonparticipants will underestimate the effects of the program. Conversely, if WIC participants are more highly motivated or better informed than nonparticipants, then studies of this type may overestimate the program's effects.

Without knowing more about the selection mechanism underlying participation, it is difficult to assess the direction of this bias. However, given that the program is locally administered, the factors governing selection into the WIC program are likely to differ considerably over time and across sites. These factors might include doctor referral, the extent 
to which WIC places are rationed, the amount of advertising, the location of WIC providers, and so on. Hence, the fact that the estimated effects are remarkably constant across samples drawn from different states at different times suggests that the positive results are not entirely driven by the selection of women who are likely to have good outcomes into the program.

Although studies of the effects of WIC on the nutrient intake of children generally find positive effects of WIC participation (cf. Fraker, $1990 \mathrm{~b}$ ), these studies are also plagued by possible selection bias. One way to control for selection effects is to follow the same child over time. The Centers for Disease Control (DHHS, 1978) report the results of a study that followed child WIC participants in six states over a two-year interval. The study found that after three WIC visits the percentage of children who were anemic fell from 23 to 10 among children 6 to 23 months of age, and from 24 to 12 among children 24 to 59 months old. In addition, 21 percent of 6 - to 23-month-old children entering the program were below the tenth percentile of length-for-age-after three WIC visits, only 15 percent of these children were below this cut-off.

Hicks et al. (1982) report encouraging results from a small-scale study of the effects of WIC participation on later cognitive development. They note that previous studies have established a link between severe malnutrition, protein deficiencies, or anemia, and cognitive deficits. The question is to what extent a less severe malnutrition or anemia threatens the development of poor children in the United States. Their study focuses on twenty-one pairs of siblings from rural Louisiana. Because of the design of the WIC program in that state, the younger child in each pair was eligible for supplementation beginning in the third trimester of pregnancy, while the older child became eligible for WIC only after the first year. The results show that the "early supplementation" group had significantly higher scores on tests of verbal ability and IQ, as well as on a "Draw-A-Person" test.

It is possible that these results are biased by the fact that the younger child always received the early supplementation. However, when the authors use measures taken when the two children were the same age, such as their grade-point averages in grade one and their heights-forage, they still find early supplementation to have a significant effect. They note in general a slight negative association between parity and IQ; so the finding that the younger children had higher IQs is unlikely to be solely an artifact of birth order.

4.2.3 School Nutrition Programs In 1979 a bipartisan Senate committee requested the secretary of agriculture to commission a study of school 
nutrition programs. This request resulted in the National Evaluation of School Nutrition Programs (NESNP), which surveyed students, parents, and school food-service administrators.

Hanes et al. (1984) use the NESNP to compare the nutritional content of the breakfasts and lunches of participants and nonparticipants. They also examine nutrient intakes over a twenty-four-hour period in order to assess the extent to which families compensate for school meals by reducing the child's home food consumption. They find that school lunches contain more of almost all the nutrients that were examined than nonparticipant lunches. The fact that school lunch participants also have higher twenty-four-hour nutrient intakes indicates that families do not entirely offset the effects of food supplementation.

The effects of the School Breakfast Program are less striking. School breakfasts contain more calcium, phosphorus, protein, and magnesium than other breakfasts, but they have less vitamin $A, B_{6}$, niacin, thiamin, and iron. Children who eat a school breakfast have higher twenty-fourhour intakes of calcium and phosphorus than those who eat an alternative breakfast, but the initial gains in intakes of other nutrients are offset during the course of the day. However, the availability of a school breakfast does have a positive effect on the probability that a child eats breakfast, and children who eat breakfast have higher twenty-four-hour nutrient intakes than children who do not.

The differences in the effects of the NSLP and the SBP on nutrient intakes probably reflect differences in federal standards. Lunches must conform to federally determined meal patterns that specify the types, amounts, and methods of food preparation. The standards for breakfasts are much looser, perhaps because the government wishes to encourage school districts to participate. The two nutrients that are consumed in greater quantities over a twenty-four-hour period by school breakfast participants are both found in milk, which is a compulsory component of the breakfast meal pattern (Radkowski and Gale, 1984a). Hence, it seems that the effectiveness of the school nutrition programs is directly related to the strictness of the federal guidelines governing them.

Surprisingly, there have been few attempts to evaluate the effects of school nutrition programs on cognitive outcomes. In one of the more compelling studies, Meyers et al. (1989) examined 1,092 third- to sixthgrade children in Lawrence, Massachusetts, before and after the SBP was introduced in their school in 1987. They found that the breakfast program participants showed greater improvements on the Comprehensive Test of Basic Skills, relative to their initial scores, than nonparticipant children. SBP participation also reduced tardiness. 
4.2.4 Head Start McKey et al. (1985) provide one of the most recent surveys of the Head Start literature. Much of the research focuses on assessing cognitive gains. The consensus of seventy-two experimental studies is that Head Start has positive effects on IQ and measures of "school readiness" that fade out by the end of the third grade. However, as discussed above, experimental evaluations of long-term outcomes may be severely biased by attrition from the sample. Also, most studies do not provide separate analyses by race, even though racial differences in the levels of scores on standardized tests suggest that the effects of Head Start may differ by race.

Currie and Thomas (1993b) use data from 1986, 1988, and 1990 waves of the NLSCM to investigate the longer-term cognitive effects of Head Start. They provide one of the first analyses of the Head Start program based on a large national sample of children who attended regular Head Start programs. About 8 percent of white children, 16 percent of Hispanic children, and 27 percent of African-American children in their sample participated. They find some evidence of longer-term cognitive gains correlated with participation in Head Start: Head Start appears to have a positive effect on the Peabody Picture Vocabulary Test (PPVT) scores of white and Hispanic children over eight years old. However, there are no effects on the PPVT scores of African-American children or on the mathematics or reading scores of any children in this age group.

Estimates based on differences between siblings are shown in Table 7 . These models control for unobserved characteristics common to both children by including a fixed effect for each family. These models also include an indicator variable equal to one if a child attended another type of preschool. Currie and Thomas find that even within the same family, children generally attend preschool when the family is relatively well off and Head Start when the family is relatively disadvantaged. Hence, the fact that Head Start has a greater impact on test scores than preschool attendance suggests that the estimated effect is unlikely to be an artifact of patterns of selection into the two types of programs.

Currie and Thomas also find that past participation in Head Start reduces the probability that white and Hispanic children ten years and older report repeating a grade. Estimates from models with fixed effects for families are shown in Table 8. Attendance at a non-Head Start preschool has no effect on the probability of grade repetition. These results are consistent with those of Copple, Cline, and Smith (1987), who followed children in thirty-three Philadelphia schools from school entry up to grade six and found that children who had participated in Head Start were 3 to 12 percent less likely to have repeated a grade (depending on 


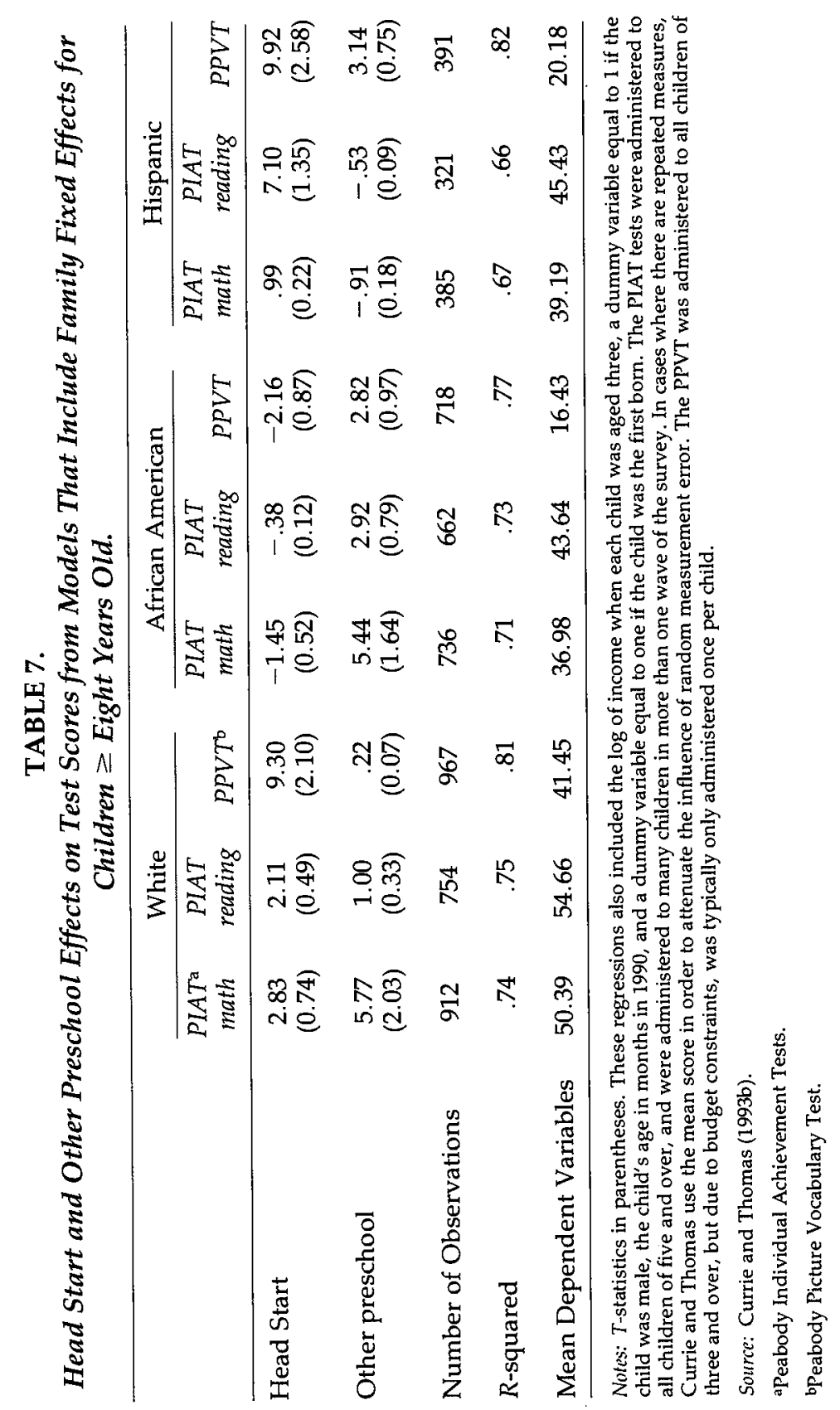


TABLE 8.

Head Start Effects on Grade Repetition, from Models That Include Family Fixed Effects, for Children $\geq$ Ten Years Old.

\begin{tabular}{lccc}
\hline & White & $\begin{array}{c}\text { African } \\
\text { American }\end{array}$ & Hispanic \\
\hline Head Start & -.51 & -.03 & -.46 \\
Other preschool & $(2.27)$ & $(.31)$ & $(2.96)$ \\
& -.08 & -.17 & -.005 \\
Log income at Age 3 & $(.67)$ & $(1.34)$ & $(.02)$ \\
& .08 & -.14 & -.38 \\
Male & $(.75)$ & $(1.10)$ & $(2.04)$ \\
Age in months in 1990 & -.06 & -.13 & -.01 \\
& $(.97)$ & $(1.93)$ & $(.09)$ \\
First born & .004 & -.001 & .01 \\
& $(1.45)$ & $(.35)$ & $(1.91)$ \\
Number of Observations & -.13 & .05 & -.16 \\
R-squared & $(1.35)$ & $(.57)$ & $(1.20)$ \\
Mean Dependent Variables & 269 & 311 & 141 \\
& .63 & .59 & .65 \\
\end{tabular}

Source: Currie and Thomas (1993b).

Note: $T$-statistics in parentheses.

the sample). They were also less likely to have been placed in remedial education. In addition, Head Start children had 2 to 23 percent fewer absences and were more likely to be present when standardized tests were administered. It would be useful to replicate these results in other data sets because the loss of 70 percent of the students in Copple, Cline, and Smith's initial sample by the sixth grade may subject their estimates to severe attrition bias.

In addition to improving cognitive attainment, Head Start aims to "provide a comprehensive health services program which includes a broad range of medical services ..." (Head Start Bureau, 1992). Thirtyfour studies reviewed by McKey et al. provide qualitative evidence that children in Head Start are more likely than nonparticipants to receive routine checkups, dental care, and screenings for speech, language, vision, hearing, and developmental delays.

Currie and Thomas (1993b) provide quantitative analyses of the effects of Head Start participation on the probability of immunization against measles as of 1990 and on height-for-age. In addition to mandating the provision of preventive medical care, the Head Start program performance standards state that "every child in a part-day program will receive a quantity of food in meals . . . and snacks which provides at least 

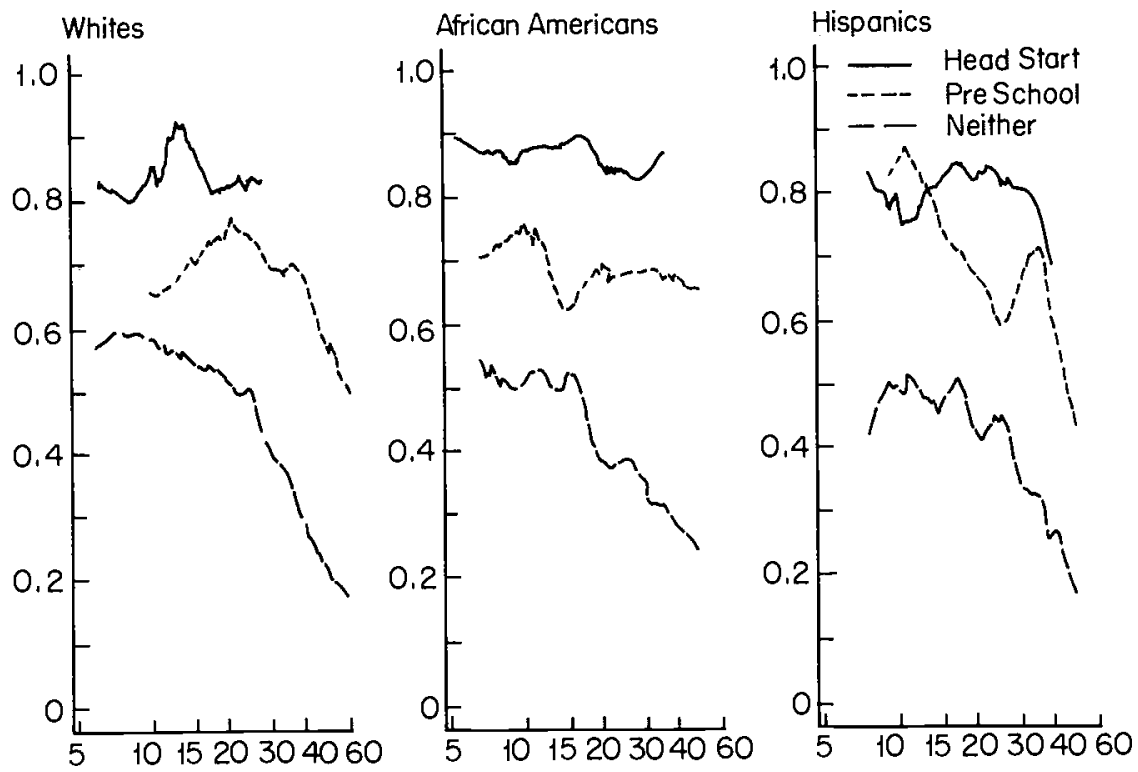

Permanent income (OOOs)

FIGURE 4. Nonparametric Estimates of the Probability of a Measles Shot by Race, Ethnicity, and Permanent Income.

Source: Currie and Thomas (1993b).

$1 / 3$ of daily nutritional needs ..." (Head Start Bureau, 1992). Both nutritious food and better medical care are expected to improve child growth. Hence, there is some reason to expect a positive effect of participation in Head Start on child height as well as on immunization rates.

Figure 4 shows nonparametric estimates of the relationship between Head Start and preschool status, permanent income, ${ }^{27}$ and immunization status in 1990. The figure shows that for white and AfricanAmerican children, the probability of having been immunized against measles is significantly higher at all income levels for children who were in Head Start relative to those who went to other preschools. ${ }^{28}$ The latter

27 Currie and Thomas (1993b) define permanent income as the logarithm of average annual household income between 1978 and 1990 (in real 1990 dollars). Use of this measure should attenuate the influence of measurement error and breaks the link between household income at a point in time and eligibility for the Head Start program. Household permanent income is about $\$ 29,000$ for the average white child, $\$ 23,000$ for Hispanics, and $\$ 18,000$ for African Americans in this sample.

${ }^{28}$ Figures 2 and 3 show locally weighted, smoothed scatterplots (LOWESS) (Cleveland, 1979), which are a nearest neighbor-type estimator. Essentially, each observation is replaced by its predicted value based on a weighted regression using the observations in a 
are, in turn, more likely to have been immunized than those who did not attend any preschool. Among Hispanics, both children who went to Head Start and those who went to other preschools are more likely to have been immunized than those who did not attend any preschool. ${ }^{29}$ Although they do not have data about the utilization of other preventive care services, Currie and Thomas suggest that if Head Start children are more likely to receive immunizations, they also may be more likely to receive the other services mandated by the program. Finally, they show that, conditional on household permanent income, children who attended Head Start are significantly taller than those who attended no preschool. These benefits of Head Start persist when family fixed effects are controlled for: Head Start participation is associated with a $10 \%$ increase in the probability that white children and a $12 \%$ increase in the probability that African-American children receive measles shots, and African-American children who attended Head Start are significantly taller than their siblings who did not. ${ }^{30}$

\section{CONCLUSIONS}

The current state of knowledge about the effects of welfare programs on child well-being is summarized in Table 9, which presents a matrix of programs and outcomes: each cell shows what we know about the effects of a particular program on a given outcome. For brevity's sake, only positive findings have been reported. The most striking feature of the table is that there are many empty cells-we clearly need to learn a great deal more about how these programs work before we can make informed public policy.

However, the cells with entries do tell a consistent story: programs that target services directly to children have the largest measured effects, whereas unrestricted cash-transfer programs have the smallest. Perhaps unsurprisingly, families seem to treat cash transfers the same way they treat other cash income. Expenditures on goods that directly increase the well-being of children may increase, but so do expenditures on other goods. As a result, large cash transfers under the NIT program had only small and inconsistent effects on the nutrition and schooling attainment of poor children.

Programs providing transfers to parents that are earmarked for specific

band around it. Hence the shape of the estimated function is determined locally throughout the distribution of income (See also Hardle, 1990).

29 All these differences are statistically significant at the 95 percent level of confidence.

${ }^{30}$ These fixed-effects estimates may be biased downward if there is measurement error, or if there are positive spill-over effects from one child to another. 


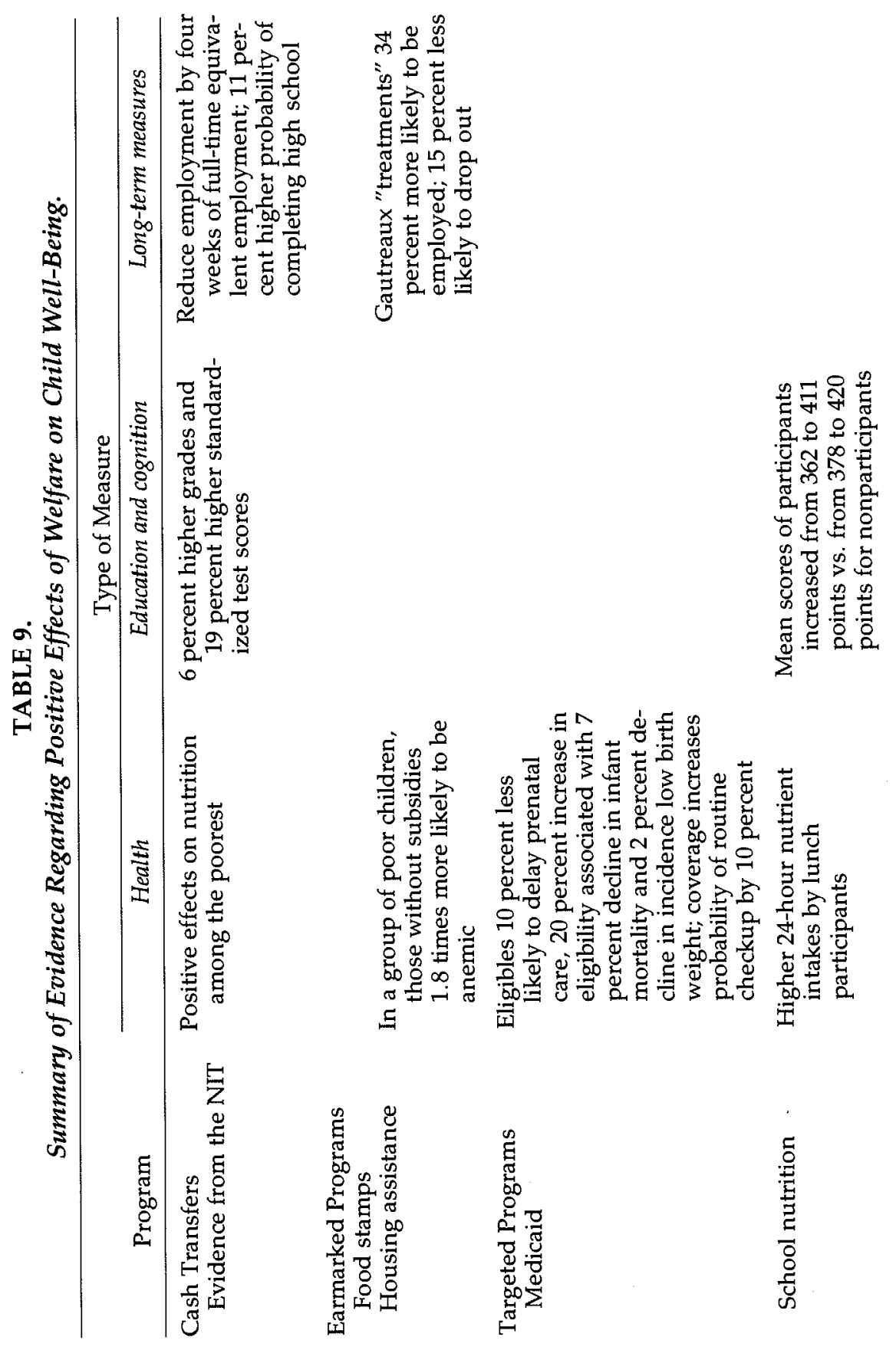




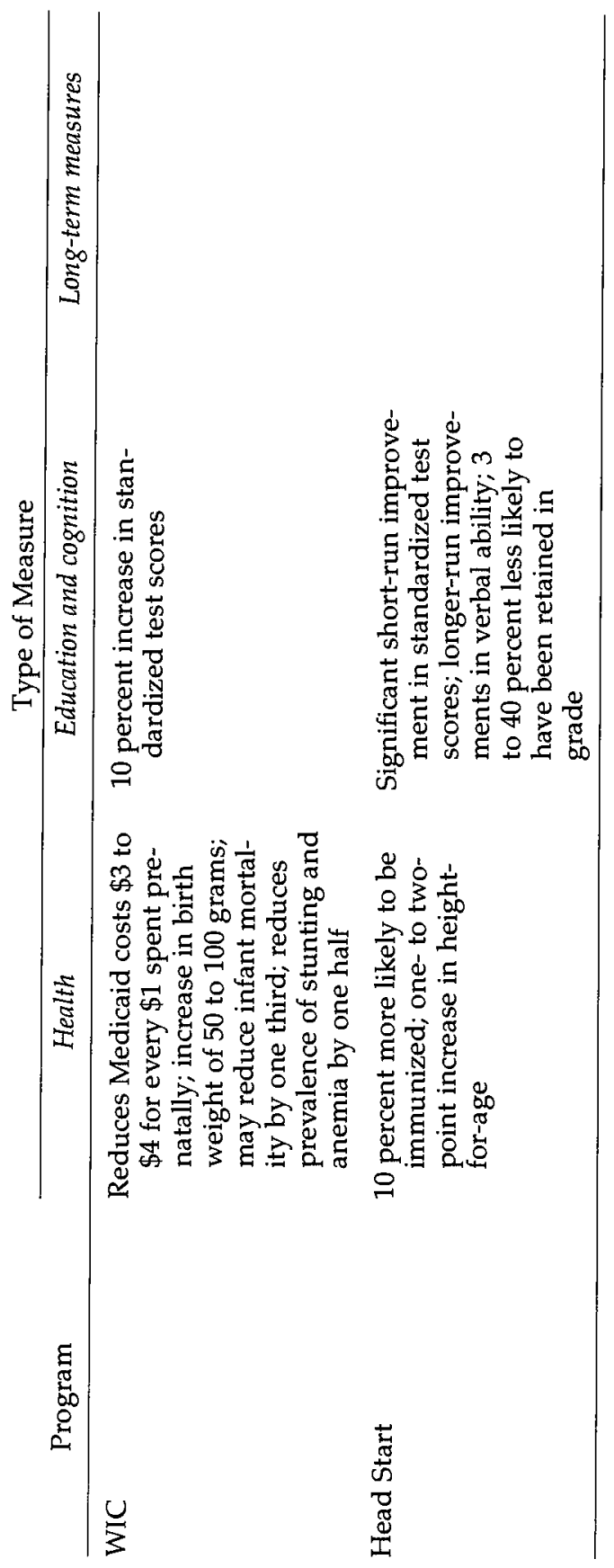


purposes also appear to have uncertain effects. There is little evidence that participation in the Food Stamp Program increases the nutrient intake of poor children, although none has proven that it does not. The evidence on housing programs is mixed. On the one hand, the physical condition of public housing may be superior to that of alternative housing, and the cash value of the transfer may be very large relative to the size of the family's income. On the other hand, the disamenities associated with large public housing complexes are notorious. The Gautreaux experiment suggests that voucher programs that enable families to move into better neighborhoods may have large positive impacts on schooling attainment and employment probabilities. But difficulties in accessing Section 8 housing probably prevent many families from realizing potential benefits. Finally, Medicaid, WIC, the School Lunch Program, and Head Start all have demonstrably positive effects on poor children.

One glaring omission from the current study is the lack of discussion about multiple program participation. Many children are covered by more than one program. For example, AFDC participants are covered by Medicaid and are automatically eligible for food stamps. As of 1990, half of AFDC children received free school lunches, 35 percent lived in public or subsidized rental housing, and 19 percent participated in WIC. Conversely, half of all food stamp recipients, 42 percent of Medicaid recipients, 38 percent of WIC recipients, and 24 percent of those in public housing also received AFDC. Moffitt (1992) estimates that in 1984, 26.4 percent of nonelderly, single-parent families received AFDC, Medicaid, and food stamps, and 11 percent received at least one benefit in addition to AFDC. It is impossible to say how multiple program participation affects the child outcomes discussed above, since there has been virtually no research on this topic.

At this point it is instructive to consider the costs as well as the benefits of two policy options. It is unlikely that AFDC benefit levels will be raised in the near future given the unpopularity of the program. However, the Omnibus Reconciliation Act of 1993 aims to raise the EITC enough over the next 5 years to "guarantee a working wage so that no American who works full-time is forced to raise children in poverty" (Clinton and Gore, 1992). In 1992, a family of four with one earner working full time at $\$ 5$ per hour (approximately the minimum wage) would have required a credit of $\$ 4,000$ to reach the poverty line. In fact, such a family received a credit of approximately $\$ 1,400$. A very crude calculation is that increasing the generosity of the program three times will raise the cost from the current $\$ 7$ billion to $\$ 21$ billion, and this increase will only benefit children of working parents.

A second, much discussed policy would extend the benefits provided 
by targeted programs to all poor children. In the absence of additional reforms, the Medicaid expansions already implemented will cover all poor children by the turn of the century. If there are approximately twelve million poor children and 28 percent of them are uninsured, ${ }^{31}$ and if the average cost of covering one of these children is equal to the current cost of covering an AFDC child, then the cost of the Medicaid expansions will be about $\$ 2.3$ billion. The costs of expanding WIC and Head Start to all eligible children would be $\$ 1.5$ and $\$ 4.5$ billion, respectively. Finally, it would cost $\$ .8$ billion to restore the cuts that have been made in the School Lunch Program. Hence, if a choice had to be made, these calculations suggest that the more cost-effective policy would be to increase expenditures on targeted programs.

\section{REFERENCES}

Angrist, Joshua (1990). "Lifetime Earnings and the Vietnam Era Draft Lottery: Evidence from Social Security Administration Records." American Economic Review, 1-336.

Apgar, William (1990). "Which Housing Policy Is Best?" Housing Policy Debate 1 (1): $1-32$.

Ashenfelter, Orley, and Mark Plant (1990). "Non-Parametric Estimates of the Labor Supply Effects of the NIT." Journal of Labor Economics 8 (1): 396-415.

Besley, Tim, and Steve Coate (1992). "Workfare vs. Welfare: Incentive Arguments for Work Requirements in Poverty Alleviation Programs" AER, 249-261.

Blanchard, Lois, et al. (1982). Food Stamp SSI/Elderly Cashout Demonstration Evaluation, Washington, DC: USDA Food and Nutrition Service.

Blank, Rebecca, and Patricia Ruggles (1993). "When Do Women Use AFDC and Food Stamps? The Dynamics of Eligibility vs. Participation." NBER Working Paper No. 4429.

Blau, Francine, and Adam Grossberg (1990). "Maternal Labor Supply and Children's Cognitive Development." NBER Working Paper No. 3536.

Bloom, Barbara (1990). "Health Insurance and Medical Care." Advance Data from Vital and Health Statistics of the National Center for Health Statistics 188. Washington, DC: Public Health Service. October 1, 1990.

Caan, Bette, Donna Horgen, Sheldon Margen, et al. (1987). "Benefits Associated with WIC Supplemental Feeding during the Interpregnancy Interval." The American Journal of Clinical Nutrition 45, 29-41.

Cain, Glen, and Douglas Wissoker (1990). "A Reanalysis of Marital Stability in the Seattle-Denver Income-Maintenance Experiment." American Journal of Sociology 95, 1235-1269.

Clarkson, Kenneth (1975). Food Stamps and Nutrition. Washington, DC: American Enterprise Institute.

Cleveland, W.S. (1979). "Robust Locally-Weighted Regressions and Smoothing Scatterplots." Journal of the American Statistical Association 74, 829-836.

31 In $1988,17 \%$ of all children and $28 \%$ of children with family incomes less than $\$ 10,000$ were without health insurance coverage of any kind (Bloom, 1990). 
Clinton, William, and Albert Gore (1992). Putting People First. New York: Times Books.

Copple, C. E., M. G. Cline, and A. N. Smith (1987). Path to the Future: Long-Term Effects of Head Start in the Philadelphia School District. Washington, DC: Head Start Bureau, U.S. Department of Health and Human Services.

Currie, Janet, and Nancy Cole (1993). "Welfare and Child Health: The Link Between AFDC Participation and Birth Weight." The American Economic Review 283 (3): 971-985.

, and Jonathan Gruber (1993). "Insurance Coverage, Access to Care, and Birth Outcomes: Evidence from Medicaid Expansions." Mimeo. National Bureau of Economic Research.

- and Duncan Thomas (1993a). "Medicaid and Medical Care for Children." NBER Working Paper No. 4284, March 1993, revised May 1993a.

— ing Paper No. 4406.

Danzinger, Sheldon, and Jonathan Stern (1990). "The Causes and Consequences of Child Poverty in the United States." Research Report No. 90-194, Population Studies Center, University of Michigan.

Desai, Sonalde, P. L. Chase-Lansdale, and Robert Michael (1989). "Mother or Market? Effects of Maternal Employment on the Intellectual Ability of 4-YearOld Children." Demography 26 (4): 545-561.

Devaney, Barbara, Linda Bilheimer, and Jennifer Schore (1990). The Savings in Medicaid Costs for Newborns and Their Mothers from Prenatal Participation in the WIC Program. Washington, DC: Mathematica Policy Research, Inc.

, Pamela Haines, and Robert Moffitt (1989). Assessing the Dietary Effects of the Food Stamp Program, Volume 2: Empirical Results. Project Nos. 7665-450 and 7665-710. Washington, DC: Mathematica Policy Research Inc.

Ellwood, David, and Mary Jo Bane (1985). "The Impact of AFDC on Family Structure and Living Arrangements." In Research in Labor Economics, 7, pp. 137-207. R. Ehrenberg, ed. Greenwich: JAI Press.

Ensminger, Margaret, and Anita Slusarcick (1992). "Paths to High School Graduation or Dropout: A Longitudinal Study of a 1st Grade Cohort." Sociology of Education 65: 95-113.

Fraker, Thomas (1990a). Analyses of the 1985 Continuing Survey of Food Intakes by Individuals, Volume II-Estimating the Effects of the WIC and Food Stamp Programs on Dietary Intake by Women and Young Children. Washington, DC: USDA Food and Nutrition Service.

$(1990 \mathrm{~b})$. The Effects of Food Stamps on Food Consumption: A Review of the Literature, Washington, DC: USDA Food and Nutrition Service.

Gottschalk, Peter (1990). "AFDC Participation across Generations." The American Economic Review 80 (2): 367-371.

Hannan, Michael, and Nancy Tuma (1990). "A Reassessment of the Effect of Income Maintenance on Marital Dissolution in the Seattle-Denver Experiment." American Journal of Sociology 95 (5): 1270-1298.

Hanes, S., J. Vermeersch, and S. Gale (1984). "The National Evaluation of School Nutrition Programs: Program Impact on Dietary Intake." The American Journal of Clinical Nutrition 40: 390-413.

Hardle, W. (1990). Applied Nonparametric Regression. New York: Cambridge University Press. 
Head Start Bureau (1992). Head Start Program Performance Standards. U.S. Department of Health and Human Services Publication No. ACF 92-31131.

Hicks, Lou, Rose Langham, and Jean Takenaka (1982). "Cognitive and Health Measures Following Early Nutritional Supplementation: A Sibling Study." American Journal of Public Health 72: 1110-1118.

Hill, Anne, and June O'Neill (1992). "The Transmission of Cognitive Achievement Across Three Generations." Mimeo. Baruch College City University of New York.

Horbar, Jeffrey, Elizabeth Wright, and Lynn Onstad (1993). "Decreasing Mortality Associated with the Introduction of Surfactant Therapy: An Observational Study of Neonates Weighing 601 to 1300 Grams at Birth." Pediatrics 82 (2): 191-196.

Institute of Medicine (1985). Preventing Low Birthweight, Washington, DC: National Academy Press.

Johnson, Gary (1986). "Rent Paying Ability and Racial Settlement Patterns: A Review and Analysis of Recent Housing Allowance Evidence." American Journal of Economics and Sociology 45 (1): 17-26.

Jones, Jean Yavis (1992). "The WIC Program: Eligibility, Coverage, and Funding." Washington, DC: Congressional Research Service.

- (1990). "Child Nutrition: Program Information, Funding, and Participation FY 1980-FY 1990." Washington, DC: Congressional Research Service.

Kehrer, Barbara, and Charles Wolin (1979). "Impact of Income Maintenance on Low Birth Weight: Evidence from the Gary Experiment." The Journal of Human Resources 14 (4): 434-462.

Kennedy, Stephen, and Merly Finkel (1987). Report of First Year Findings for the Freestanding Housing Voucher Demonstration. Cambridge, MA: ABT Associates, Inc.

Korenman, Sanders, and Jane Miller (1992). Food Stamp Program Participation and Maternal and Child Health. Draft Report to the Food and Nutrition Service of the United States Department of Agriculture.

Lazere, Edward, Paul Leanard, Cushing Dolbeare, and Barry Zigas (1991, December). A Place to Call Home: The Low Income Housing Crisis Continues. Washington, DC: The Center on Budget and Policy Priorities.

Mallar, Charles (1977). "The Educational and Labor Supply Responses of Young Adults on the Urban Graduated Work Incentive Experiment." In The New Jersey Income Maintenance Experiments. Harold Watts and Albert Rees, eds. New York: Academic Press.

Massachusetts Department of Health, Division of Family Services (1983). 1983 Massachusetts Nutrition Survey. Boston: Department of Health.

Maynard, Rebecca, and David Crawford (1976). "School Performance." Rural Income Maintenance Experiment: Final Report. Madison, WI: Institute for Research on Poverty.

- and Richard Murnane (1979). "The Effects of a Negative Income Tax on School Performance: Results of an Experiment." The Journal of Human Resources 14 (4).

McKey, Ruth, et al. (1985). The Impact of Head Start on Children, Families and Communities: Final Report of the Head Start Evaluation, Synthesis and Utilization Project. Washington, DC: CSR, Incorporated.

Metcoff, Jack, et al. (1985). "Effect of Food Supplementation (WIC) During Pregnancy on Birth Weight." The American Journal of Clinical Nutrition 41. 
Meyers, Alan, Amy Sampson, Michael Weitzman, and Herb Kayne (1989). "School Breakfast Program and School Performance." American Journal of Diseases of Children 143 (N10): 1234-1239.

_ Dana Rubin, Maria Napoleone, and Kevin Nichols (1993). "Public Housing Subsidies May Improve Poor Children's Nutrition." American Journal of Public Health 83 (1): 115.

Michael, Robert (1978). "The Consumption Studies." In Welfare in Rural Areas: The Iowa Income Maintenance Experiment. John Palmer and Joseph Pechman, eds. The Brookings Institution: Washington, DC.

Mitchell, Janet, and Rachel Shurman (1984). "Access to Private Obstetrics/ Gynecology Services Under Medicaid." Medical Care 22: 1026-1037.

Moffitt, Robert (1992). "Incentive Effects of the U.S. Welfare System: A Review." Journal of Economic Literature 30: 1-61.

- (1989). "Estimating the Value of an In-Kind Transfer: The Case of Food Stamps." Econometrica 57 (2): 385-410.

Moore, Kristin, and Steven Caldwell (1977). "The Effect of Government Policies on Out-of-Wedlock Sex and Pregnancy." Family Planning Perspectives 9 (4): 164169.

Mulroy, Elizabeth (1988). "The Search for Affordable Housing." In Women as Single Parents: Confronting the Institutional Barriers in the Courts, the Workplace and the Housing Market. E. Mulroy, ed. New York: Auburn House.

Murray, Charles (1984). Losing Ground. New York: Basic Books.

Newhouse, Joseph (1992). "Medical Care Costs: How Much Welfare Loss?" Journal of Economic Perspectives 6 (3): 3-22.

Nichols, Albert, and Richard Zeckhauser (1982). "Targeting Transfers through Restrictions on Recipients" American Economic Review 72(2): 372-377.

O'Conner, Frank, Patrick Madden, and Allen Pringle (1976). "Nutrition." Rural Income Maintenance Experiment: Final Report. Madison, WI: Institute for Research on Poverty.

Pedone, Carla (1988). Current Housing Problems and Possible Federal Responses, Washington, DC: Congressional Budget Office.

Radzikowski, Jack, and Steven Gale (1984a). "The National Evaluation of School Nutrition Programs: Conclusions." The American Journal of Clinical Nutrition 40: 454-461.

- (1984b). "Requirement for the National Evaluation of School Nutrition Programs." The American Journal of Clinical Nutrition 40: 365-367.

Robins, Philip (1985). "A Comparison of the Labor Supply Findings from the Four Negative Income Tax Experiments." Journal of Human Resources, 20 (4): 567-582.

Rosenbaum, James (1992). "Black Pioneers-Do Their Moves to the Suburbs Increase Economic Opportunity for Mothers and Children?" Housing Policy Debate 2 (4): 1179-1213.

- L. S. Rubinowitz, and M. J. Kulieke (1986). Low Income African-American Children in White Suburban Schools. Evanston, IL: Center for Urban Affairs and Policy Research, Northwestern University.

Schramm, Wayne (1985). "WIC Prenatal Participation and Its Relationship to Newborn Medicaid Costs in Missouri: A Cost/Benefit Analysis." American Journal of Public Health, 75 (8).

Starfield, Barbara (1985). Effectiveness of Medical Care: Validating Clinical Wisdom. Baltimore: Johns Hopkins University Press. 
Stewart, Anne (1992). Head Start: Funding Eligibility and Participation. Washington, DC. CRS Report for Congress.

Thomas, Duncan (in press). "Like Father Like Son, Or, Like Mother Like Daughter: Parental Education and Child Health." Journal of Human Resources.

U.S. Department of Health and Human Services, Centers for Disease Control, Public Health Service (1978). CDC Analysis of Nutritional Indices for Selected WIC Participants. FNS-176.

U.S. House of Representatives, Committee on Ways and Means (1992). Overview of Entitlement Programs: 1992 Green Book. Washington, DC: U.S. Government Printing Office.

(1991). 1991 Green Book: Background Material and Data on Programs within the Jurisdiction of the Committee on Ways and Means. WMCP-102-9. Washington, DC: U.S. Government Printing Office.

Venti, Steven (1984). "The Effects of Income Maintenance on Work, Schooling, and Non-Market Activities of Youth. "Review of Economics and Statistics 66 (1): 16-25.

Zimmerman, David, and Phillip Levine (1993). "The Intergenerational Correlation in AFDC Participation: Welfare Trap or Poverty Trap." Mimeo. Williams College. 
